\title{
Predictions of ruminal outflow of essential amino acids in dairy cattle
}

\author{
A. J. Fleming, ${ }^{1} \oplus$ H. Lapierre, ${ }^{2} \odot$ R. R. White, ${ }^{1,3}$ H. Tran,,${ }^{3,4}$ P. J. Kononoff, ${ }^{4} \odot$ R. Martineau, ${ }^{2}$ W. P. Weiss, ${ }^{5} \odot$ \\ and M. D. Hanigan ${ }^{1 *}$ (1) \\ ${ }^{1}$ Department of Dairy Science, Virginia Tech, Blacksburg 24061 \\ ${ }^{2}$ Agricultural and Agri-Food Canada, Sherbrooke, QC, Canada J1M 0C8 \\ ${ }^{3}$ National Animal Nutrition Program, National Research Support Project, USDA, Washington, DC 20250 \\ ${ }^{4}$ Department of Animal Science, University of Nebraska, Lincoln 68583 \\ ${ }^{5}$ Department of Animal Sciences, The Ohio State University, Columbus 43210
}

\section{ABSTRACT}

The objective of this work was to update and evaluate predictions of essential AA (EAA) outflows from the rumen. The model was constructed based on previously derived equations for rumen-undegradable (RUP), microbial (MiCP), and endogenous (EndCP) protein outflows from the rumen, and revised estimates of ingredient composition and EAA composition of the protein fractions. Corrections were adopted to account for incomplete recovery of EAA during 24-h acid hydrolysis. The predicted ruminal protein and EAA outflows were evaluated against a data set of observed values from the literature. Initial evaluations indicated a minor mean bias for non-ammonia, non-microbial nitrogen flow ([RUP + EndCP $] / 6.25)$ of $16 \mathrm{~g}$ of $\mathrm{N}$ per day. Root mean squared errors (RMSE) of EAA predictions ranged from 26.8 to $40.6 \%$ of observed mean values. Concordance correlation coefficients (CCC) of EAA predictions ranged from 0.34 to 0.55 . Except for Leu, all ruminal EAA outflows were overpredicted by 3.0 to 32 $\mathrm{g} / \mathrm{d}$. In addition, small but significant slope biases were present for Arg [2.2\% mean squared error (MSE)] and Lys $(3.2 \% \mathrm{MSE})$. The overpredictions may suggest that the mean recovery of AA from acid hydrolysis across laboratories was less than estimates encompassed in the recovery factors. To test this hypothesis, several regression approaches were undertaken to identify potential causes of the bias. These included regressions of (1) residual errors for predicted EAA flows on each of the 3 protein-driven EA flows, (2) observed EAA flows on each protein-driven EAA flow, including an intercept, (3) observed EAA flows on the protein-driven EAA flows, excluding an intercept term, and (4) observed

Received January 14, 2019.

Accepted May 29, 2019.

*Corresponding author: mhanigan@vt.edu
EAA flows on RUP and MiCP. However, these equations were deemed unsatisfactory for bias adjustment, as they generated biologically unfeasible predictions for some entities. Future work should focus on identifying the cause of the observed prediction bias.

Key words: mechanistic model, amino acid, ruminal outflow, tissue

\section{INTRODUCTION}

Protein supplementation represents a substantial proportion of the total cost of dairy rations, and in many cases dairy cows are fed protein in excess of their requirements. Overfeeding protein results in inefficient $\mathrm{N}$ use, causing excess $\mathrm{N}$ to be excreted into the environment and unnecessarily increasing feeding costs ( $\mathrm{Pa}-$ checo et al., 2012). One reason protein may be overfed is that protein supply and requirements are generally stated in MP terms; however, the true requirements are for EAA within that protein. To ensure that variation in the EAA composition of the MP supply does not contribute to production losses, nutritionists feed protein above true EAA requirements either to overcome the variance in EAA composition or as a safety margin against uncertainty in composition and intake. To balance rations on an EAA basis (i.e., EAA supply matches requirements), reducing the excess $\mathrm{N}$ supply, requires accurate and precise predictions of both EAA supply and requirements.

Several ration formulation systems have been developed and evaluated over the last 3 decades, including the Nutrient Requirements of Dairy Cattle from the National Research Council (NRC, 2001), the Cornell Net Carbohydrate-Protein System (CNCPS; Fox et al., 2004), the feeding system guidelines of the Institut National de la Recherche Agronomique (INRA, 2018), the Dutch DVE/OEB system (Tamminga et al., 1994), the British Feed Into Milk model (Offer et al., 2002), and the Scandinavian NorFor evaluation system (Volden, 2011). These models all predict ruminal protein outflow 
as a function of DMI and ration composition. The NRC (2001) model predictions of microbial N (MiN) have been evaluated and reported to have a relatively small $(27 \mathrm{~g} / \mathrm{d})$ but significant $(P=0.02)$ mean bias over the range of data evaluated (St-Pierre, 2003). Predictions of non-ammonia, non-microbial N (NANMN) flow from NRC (2001) had significant linear bias when compared with experimental data (Bateman et al., 2005). Pacheco et al. (2012) subsequently evaluated the duodenal EAA flow predictions from different feeding systems and reported that the predicted duodenal flows of Arg and His were underestimated compared with observed flows when using the NRC (2001), whereas duodenal flow of all EAA except for Leu and Thr were overestimated when using the Agricultural Modeling and Training Systems (AMTS) or the Cornell-PennMiner (CPM) system. The NRC (2001) model predicts ruminal EAA outflows from dietary protein based on predictions of the fraction of protein from each feed that escapes ruminal degradation and the EAA composition of the feed protein. The summation of the individual feed EAA contributions is subsequently adjusted empirically for each EAA, based on the proportion of RUP in the total duodenal protein flow. It is possible that these empirical adjustments were required due to biased predictions of protein outflows or biased estimates of the EAA composition of those proteins.

The objectives of this work were (1) to construct a revised model of rumen EAA outflows based on updat- ed predictions of RUP and microbial and endogenous protein flows (MiCP and EndCP, respectively) and revised EAA compositions of each protein fraction; and (2) to evaluate predictions of ruminal EAA outflows by the revised model, using literature data reporting observed post-ruminal flows of EAA.

\section{MATERIALS AND METHODS}

\section{Metadata}

The data set used to evaluate prediction models for MiN and RUP included studies used by White et al. (2017b) plus studies listed in Table 1. The data set used to evaluate predicted EAA flows included a subset of those studies that reported ruminal EAA outflow (Table 2). Summary statistics for these data sets are listed in Table 3. A mixture of duodenal and omasal sampling techniques were used in the studies, with $18 \%$ of the studies using omasal sampling $(\mathrm{n}=118$ treatment means) and $82 \%$ using duodenal sampling ( $\mathrm{n}=$ 549 treatment means) in the full protein data set. The sampling distribution for the EAA data set was similar, with $20 \%$ using omasal sampling $(\mathrm{n}=52$ treatment means) and $80 \%$ using duodenal sampling $(\mathrm{n}=202$ treatment means).

Observations were deemed outliers if they were more than 3 standard deviations (SD) from the mean and were excluded before model parameterization and as-

Table 1. Studies used in addition to that of White et al. (2017b) for model evaluation of protein outflows from the rumen

Citation

Appuhamy et al. (2011)

Arriola Apelo et al. (2014)

Benefield et al. (2009)

Blum et al. (1999)

Broderick et al. (2008)

Chow et al. (1990)

Davidson et al. (2008)

Drackley and Elliott (1993)

Giallongo et al. (2016)

Jenkins and Jenny (1989)

Kröber et al. (2000)

Leonardi et al. (2003)

Madsen (1986)

Ohajuruka et al. (1991)

Overton et al. (1998)

Pantoja et al. (1996)

Piantoni et al. (2013)

Pisulewski et al. (1996)

Pruekvimolphan and Grummer (2001)

Rogers et al. (1987)

Samuelson et al. (2001)

Socha et al. (2005)

Vanhatalo et al. (1999)

Weiss and Wyatt (2004)
Ardalan et al. (2010)

Benchaar et al. (1991)

Berthiaume et al. (2001)

Boerman et al. (2017)

Chen et al. (2011)

Colmenero and Broderick (2006b)

de Souza et al. (2017)

Drackley et al. (1994)

Girard et al. (2005)

Kowalski et al. (2003)

Kudrna et al. (2009)

Loor et al. (2002)

Misciatteilli et al. (2003)

Oliveira et al. (1995)

Overton et al. (1996)

Papas et al. (1984a)

Piantoni et al. (2015)

Polan et al. (1991)

Rico et al. (2014)

Rulquin and Delaby (1997)

Simas et al. (1997)

Soder and Holden (1999)

Varvikko et al. (1999)

Wonsil et al. (1994)

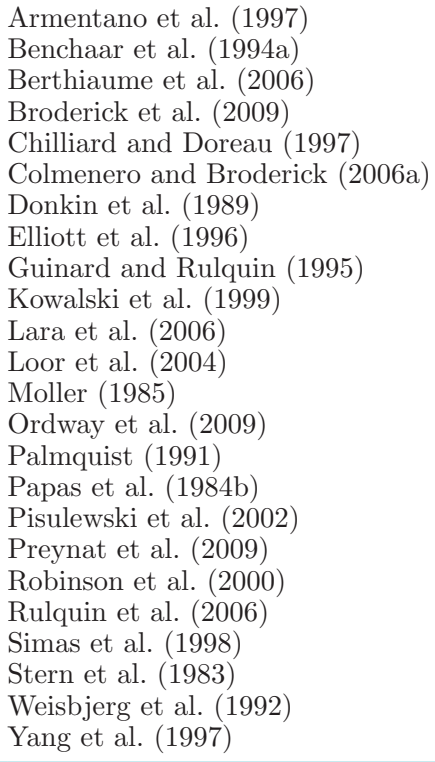


Table 2. Studies used for model evaluations of EAA outflows from the rumen

\section{Citation}

Ahvenjärvi et al. (2002)

Benchaar et al. (1994a)

Blauwiekel et al. (1997)

Brito et al. (2007b)

Cameron et al. (1991)

Christensen et al. (1996)

Erasmus et al. (1994)

Halmemies-Beauchet-Filleau et al. (2014)

Ipharraguerre et al. (2005b)

King et al. (1990)

Klusmeyer et al. (1991b)

Mabjeesh et al. (1996)

McCarthy Jr. et al. (1989)

Narasimhalu et al. (1989)

Overton et al. (1995)

Prange et al. (1984)

Reynal and Broderick (2003)

Robinson et al. (1994)

Schwab et al. (1992a)

Stern et al. (1985)

Van Vuuren et al. (1992)

Windschitl et al. (1988)
Aldrich et al. (1993)

Benchaar et al. (1994b)

Brito and Broderick (2006)

Brito et al. (2009)

Chibisa et al. (2012)

Cunningham et al. (1993)

Eramus et al. (1992)

Ipharraguerre et al. (2002)

Jones-Endsley et al. (1997)

Klusmeyer et al. (1990)

Korhonen et al. (2002)

Mabjeesh et al. (1997)

Merchen and Satter (1983)

O'Mara et al. (1997)

Palmquist et al. (1993)

Price et al. (1988)

Reynal et al. (2005)

Robinson (1997)

Schwab et al. (1992b)

Teller et al. (1992)

Volden (1999)

Yang and Beauchemin (2004)
Armentano et al. (1986)

Bernard et al. (2004)

Brito et al. (2007a)

Broderick and Reynal (2009)

Christensen et al. (1993)

Cunningham et al. (1994)

Fanchone et al. (2013)

Ipharraguerre et al. (2005a)

Joy et al. (1997)

Klusmeyer et al. (1991a)

Lynch et al. (1991)

Mansfield and Stern (1994)

Murphy et al. (1987)

O'Mara et al. (1998)

Pena et al. (1986)

Putnam et al. (1997)

Reynal et al. (2007)

Santos et al. (1984)

Stern et al. (1983)

Vanhatalo et al. (2009)

Waltz et al. (1989)

Zerbini et al. (1988) sessment (4 NANMN treatment means were removed from the protein data set). Dietary inputs to the model were derived from a combination of observed and tabular values as described by Hanigan et al. (2013) and Li et al. (unpublished data). Briefly, the reported nutrient composition of dietary ingredients was used when available. No studies in the data set reported all values required to conduct the work, and thus a feed library,

Table 3. Statistical summary of literature data used to evaluate prediction models

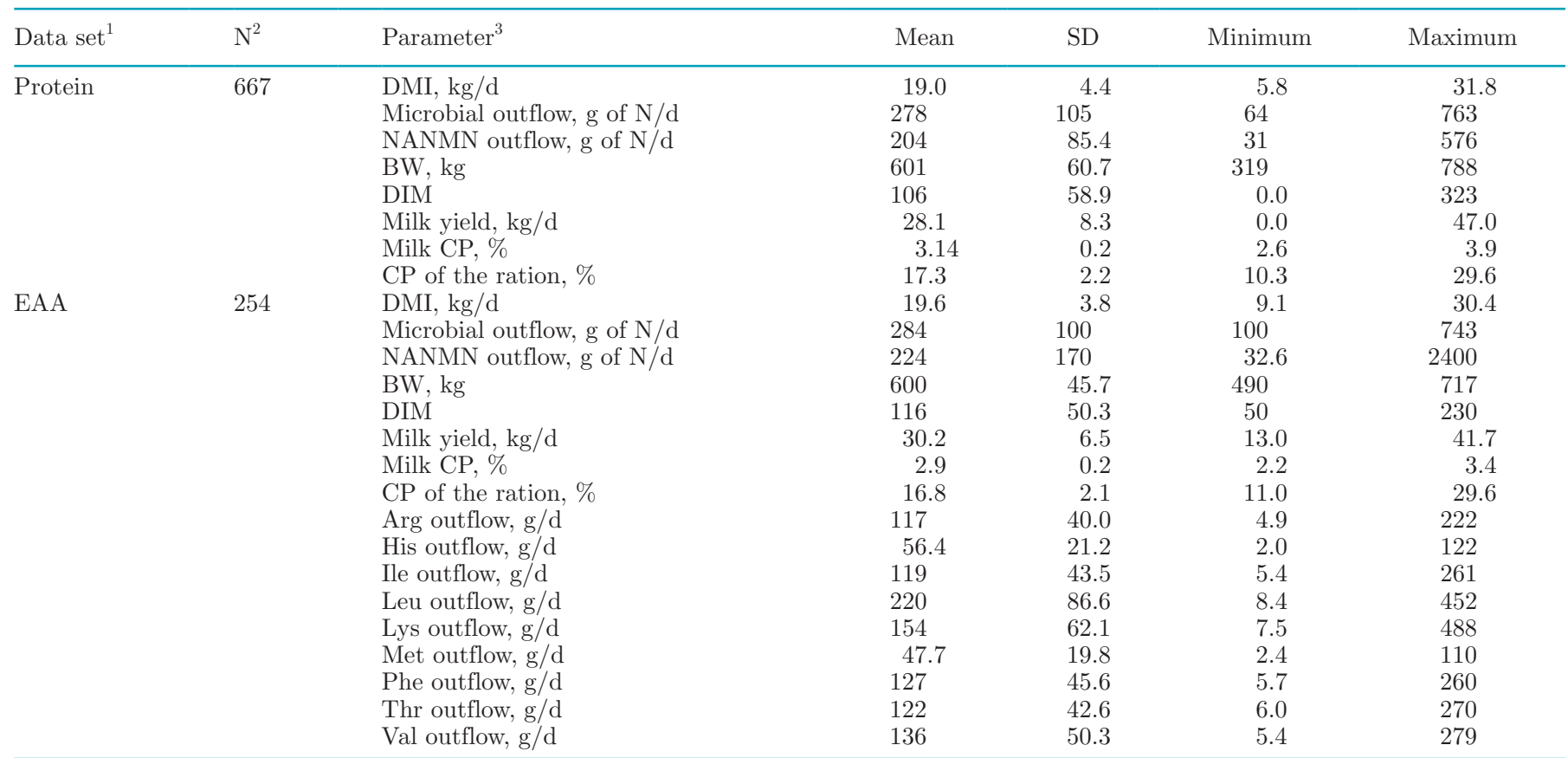

${ }^{1}$ Protein $=$ studies used for model evaluation of ruminal outflow of proteins (Table 1 ); EAA = studies used for model evaluation of ruminal outflow of EAA (Table 2).

${ }^{2} \mathrm{~N}=$ number of observations.

${ }^{3} \mathrm{NANMN}=$ non-ammonia, non-microbial nitrogen. 
constructed from a combination of the NRC (2001) feed library, a library derived from commercial laboratory data (collected by the National Animal Nutrition Program, www.animalnutrition.org; Tran et al., 2019), and the CNCPS feed library, was used to generate missing values for each study. Where duplicate nutrient information occurred, precedence was generally given to the commercial feed library, followed by the NRC (2001) library, followed by the CNCPS library. In general, the proximate nutrients and protein fractions came from the commercial library, and EAA composition came from the CNCPS library (Higgs et al., 2015). The calculated dietary nutrient intakes from each ingredient were subsequently summed by diet and compared with observed dietary $\mathrm{CP}, \mathrm{ADF}, \mathrm{NDF}$, starch, FA, and ether extract intakes, and mean bias by study for each nutrient was calculated. It was assumed that this bias reflected nutrient specification bias due to the use of varying amounts of library data, although sampling and analytical error within each study cannot be ruled out. The mean bias for each study was used to adjust the nutrient content of each ingredient in the study, with weighting by the contribution of that ingredient to the overall study nutrient sum. The SD of the adjustment factors was determined for each nutrient across studies, and nutrient adjustments were truncated to $\pm 1 \mathrm{SD}$ before use in adjusting ingredient values (Bateman et al., 2008). This approach preserves the variance among diets but removes the mean bias for the study. All of the metadata are available on the National Animal Nutrition Program website (www.animalnutrition.org).

\section{Model Derivation}

The model developed by White et al. (2017a) was used to predict RUP content $\left(R U P_{f, d}, \mathrm{~g} / \mathrm{g}\right)$ for each feed $(f)$ within a diet $(d)$, and RUP flow and the AA $(i)$ associated with that flow $\left(R U P A A_{i, d}, \mathrm{~g} / \mathrm{d}\right)$ were calculated by summation for each diet:

$$
\begin{aligned}
& R U P_{f, d}=\left[\alpha\left(C P a_{f, d}\right)+\beta\left(C P b_{f, d}\right)+C P c_{f, d}\right] \\
& R U P_{d}=\sum_{f=1}^{n}\left[\frac{R U P_{f, d}}{100} \times\left(D M I_{d} \times \frac{D M I p_{f, d}}{100}\right)\right] \times 1,000 \\
& R U P A A_{i, d}=\sum_{f=1}^{n}\left[\begin{array}{l}
\frac{F d A A_{i, f}}{R e c A A_{i} \times 100} \times \frac{R U P_{f, d}}{100} \times \\
\left(D M I_{d} \times \frac{D M I p_{f, d}}{100}\right)
\end{array}\right] \times 1,000,
\end{aligned}
$$

where $\alpha$ and $\beta$ were feed class-specific fractional passage coefficients; $C P a_{f, d}(\%$ of $\mathrm{DM})=\mathrm{CP}$ that escapes from a ruminally incubated Dacron bag at time 0 for feed $f$ within diet $d ; C P b_{f, d}(\%$ of $\mathrm{DM})=\mathrm{CP}$ that is insoluble and potentially degradable in the rumen for feed $f$ within diet $d ; C P c_{f, d}(\%$ of $\mathrm{DM})=\mathrm{CP}$ that is undegradable in the rumen for feed $f$ within diet $d$; and $F d A A_{i, f}$ represented the content of each $\mathrm{AA}$ in a feed (grams of AA per grams of $\mathrm{CP}$ ), which were provided for use in the CNCPS library by Evonik (Hanau, Germany) as a complete data set reflecting their historical feed evaluations. In our model, $D M I_{d}$ was dietary DMI in kilograms per day; and $D M I p_{f, d}$ represented the dietary inclusion rate of each feed (\% of DM). RecAA represented the recovery factor accounting for incomplete recovery of AA from a 24-h acid hydrolysis (grams per grams of true AA; Table 4), which was adapted from Lapierre et al. (2016b) by simple inversion of the factors. These are necessary, as recovery levels vary among AA based on their chemical characteristics. For example, the full release of the branched-chain AA (Ile, Leu, and Val) requires more than $24 \mathrm{~h}$ of acid hydrolysis due to the stable nature of peptide bonds formed with those AA (Blackburn, 1968), whereas the recovery of less-stable EAA (e.g., Thr) is incomplete due to partial degradation of the released AA during the $24 \mathrm{~h}$ of hydrolysis (Rees, 1946). Similarly, the recovery factors listed in Table 4 were used when calculating the microbial and endogenous protein flows to account for incomplete recovery of AA from a 24-h acid hydrolysis.

Equation [2], from Roman-Garcia et al. (2016), was used to predict MiN flows (grams per day):

$$
\begin{aligned}
& \text { MiN }_{d}=-52.2+122 \times S M P \text { Loc }_{d}+12.5 \times D M I_{d}+1.23 \\
& \times R D S t p_{d}+2.23 \times \frac{R D S t_{d}}{R D N D F_{d}},
\end{aligned}
$$

where $S M P L o c_{d}$ was the sampling location $(0=$ duodenal and $1=$ omasal); $R D S t p_{d}$ was the apparent ruminal digestibility of starch (\% of starch intake) for each diet; and $R D S t_{d}$ and $R D N D F_{d}$ represented the amount of starch and NDF degraded in the rumen (kilograms per day), respectively. The parameters $R D S t_{d}$ and $R D N D F_{d}$ were predicted using Equations [4] and [5] of White et al. (2016) with an intercept adjustment to address a significant mean bias $(P<0.001)$ observed in initial model evaluations:

$$
\begin{aligned}
R D S t p_{d} & =58.5-1.45 \times D M I_{d}+0.424 \times N D F_{\text {Forage }, d} \\
& +1.39 \times S t_{d}-0.0219 \times S t_{d}^{2}-0.154 \times \text { Forage }_{W e t, d},
\end{aligned}
$$


Table 4. Acid hydrolysis recovery factors and corrected EAA profiles of microbial true protein (MiTP) and endogenous crude protein (EndCP)

\begin{tabular}{lccc}
\hline Item & Recovery $^{1}$ & MiTP profile $^{2}$ & EndCP profile $^{3}$ \\
\hline Arginine & 0.97 & 5.29 & 4.49 \\
Histidine & 0.98 & 2.08 & 2.75 \\
Isoleucine & 0.89 & 6.95 & 4.09 \\
Leucine & 0.93 & 9.22 & 7.70 \\
Lysine & 0.94 & 9.37 & 6.22 \\
Methionine & 0.95 & 2.61 & 1.26 \\
Phenylalanine & 0.91 & 6.43 & 5.09 \\
Threonine & 0.95 & 6.29 & 5.33 \\
Valine & 0.90 & 6.90 & \\
\hline
\end{tabular}

${ }^{1}$ Factors indicating the incomplete recovery of AA obtained after 24-h hydrolysis [1/correction factors proposed by Lapierre et al. (2016b)].

${ }^{2}$ Grams of AA per $100 \mathrm{~g}$ of true protein, corrected to account for incomplete recovery with a 24-h acid hydrolysis (Sok et al., 2017)

${ }^{3}$ Grams of AA per $100 \mathrm{~g}$ of CP; from Orskov et al. (1986) corrected for incomplete recovery with a 24-h acid hydrolysis (Lapierre et al., 2016b).

$$
\begin{gathered}
R D S t_{d}=\frac{R D S t p_{d}}{100} \times \text { StIn }_{d} \\
R D N D F p_{d}=-31.9+0.721 \times N D F_{d}-0.247 \times S t_{d}+6.63 \\
\times C P_{d}-0.211 \times C P_{d}^{2}-0.387 \times \frac{A D F_{d}}{N D F_{d}} \times 100 \\
-0.121 \times \text { Forage }_{W e t, d}+1.51 \times D M I_{d} \\
R D N D F_{d}=\frac{R D N D F p_{d}}{100} \times\left(N D F I n_{d}\right)
\end{gathered}
$$

where $S t I n_{d}$ and $N D F I n_{d}$ represented dietary intakes of starch and NDF (kilograms per day), respectively. Forage NDF $\left(N D F_{\text {Forage,d }}\right)$, dietary starch $\left(S t_{d}\right)$, wet forage (Forage $\left._{W e t, d}\right), N D F_{d}, C P_{d}$, and $A D F_{d}$ were all expressed as a proportion of the dry matter from wet forage in the diet.

Microbial $\mathrm{N}$ flows from Equation [2] were converted to a true protein basis ( $\boldsymbol{M i T P}$, grams per day) assuming $16 \% \mathrm{~N}$ and $0.824 \mathrm{~g}$ of true protein per gram of $\mathrm{CP}$ (Sok et al., 2017):

$$
M i T P_{d}=M i N_{d} \times 6.25 \times 0.824 .
$$

The microbial EAA ( $M i E A A_{i, d}$, grams per day) flow to the duodenum was calculated as the product of $M i T P_{d}$ and the EAA profile of microbial protein $\left(\right.$ MiProf $_{i}$, grams of EAA per $100 \mathrm{~g}$ of MiTP; Table 4):

$$
\operatorname{MiEAA}_{i, d}=\operatorname{MiTP}_{d} \times \frac{\operatorname{MiProf}_{i}}{100}
$$

where $i$ represented each individual EAA (Arg, His, Ile, Leu, Lys, Met, Phe, Thr, Val). The AA profile reflects a mix of fluid-associated bacteria, particle-associated bacteria, and protozoa (Sok et al., 2017), with corrections for incomplete recovery during hydrolysis.

Endogenous crude protein flowing at the duodenum (EndCP, g/d) was predicted using the equation of Lapierre et al. (2016a):

$$
\operatorname{EndCP}_{d}=\left(15.4+1.21 \times D M I_{d}\right) \times 6.25,
$$

where $D M I$ was in kilograms per day. Total non-ammonia, non-microbial CP outflow $\left(N A N M C P_{d}, \mathrm{~g} / \mathrm{d}\right)$ was the sum of RUP and endogenous protein flows:

$$
N A N M C P_{d}=R U P_{d}+E n d C P_{d} .
$$

The flow of each EAA associated with endogenous protein $\left(E n d A A_{i, d}, \mathrm{~g} / \mathrm{d}\right)$ was estimated as the product of $E_{n d C P_{d}}$ multiplied by its EAA profile (EndProf $f_{i}$, g of AA per $100 \mathrm{~g}$ of $\mathrm{CP}$; Table 4):

$$
\operatorname{EndAA}_{i, d}=\operatorname{EndCP}_{d} \times \frac{\text { EndProf }_{i}}{100} .
$$

The AA profile was estimated as the mean of the ruminal and abomasal isolates from Orskov et al. (1986), except for Leu, where only the ruminal isolate was retained and therefore the AA profile was estimated only using the ruminal isolate. As for the other proteins, the observed profile was corrected for incomplete recovery during hydrolysis. 
Total ruminal EAA outflows (EAA $A_{\text {outflow,i,d }}$, grams per day) were the sum of AA flows from the 3 protein sources:

$$
E A A_{\text {outflow }}=\left(R U P A A_{i, d}+M i E A A_{i, d}+E n d A A_{i, d}\right) .
$$

Because all EAA flows represented our best estimates of the true flow, an additional set of flow predictions were required for direct comparison to observations from 24-h hydrolysis reported in the literature. This was achieved by multiplying the predicted true flows by the recovery factors listed in Table $4\left(\operatorname{Rec} A A_{i, d}\right)$ :

$$
\begin{aligned}
& \operatorname{EAA}_{\text {outflow }-24 h_{i, d}}=\left(\operatorname{RUPAA}_{i, d}+\operatorname{MiEAA}_{i, d}+\operatorname{EndAA}_{i, d}\right) \\
& \times \operatorname{RecA} A_{i, d} .
\end{aligned}
$$

\section{Evaluating Prediction Errors}

All work was conducted using R (Ver. 3.2.2; R Core Team, 2015) unless otherwise specified. Linear mixed effects regression was conducted using the lmer function of the lme4 package (Kuznetsova et al., 2017). When deriving EAA bias adjustments, EAA flow residuals were initially regressed on each of the individual protein flows, including a random effect of study in the model. Subsequently observed total EAA flows were regressed on the individual protein EAA flows both with and without random study effects. An additional bias adjustment was evaluated, where observed total EAA flows were regressed only on RUP and MiCP EAA flows with random study effects. Backward elimination was used to evaluate the bias adjustment approaches, with a significance level of 0.05 used for elimination of factors from the model. Model performance was evaluated using root mean squared error (RMSE) as described by Bibby and Toutenburg (1978), concordance correlation coefficient (CCC) as described by Lin (1989), and mean and slope bias with a significance level of 0.05. Variance associated with mean and slope biases was expressed as a percentage of mean squared error (MSE), and considered small, moderate, or large if $<5 \%, 5-10 \%$, or $>10 \%$, respectively.

\section{RESULTS AND DISCUSSION}

Initial evaluations of rumen protein outflows showed a small mean bias for NANMN (Table 5). Although significant $(P<0.01)$, it was biologically irrelevant at $16 \mathrm{~g}$ of nitrogen per day, representing $4 \%$ of MSE, and thus NANMN was deemed adequate for further work (Figure 1). We found no mean or slope bias for MiN predictions (Figure 2), and it was also deemed adequate for further work (Table 5), although a single study appeared to possibly be an outlier.

Evaluations of predicted flows, adjusted to reflect incomplete recovery from acid hydrolysis and observed ruminal EAA outflows, showed significant mean bias $(P<0.05)$ for all EAA except Leu and significant slope bias $(P<0.05)$ for Arg and Lys (Table 5$)$. The residual plots for 4 EAA (His, Lys, Met, and Val) are shown in Figure 3. Mean bias ranged from 0.00 to $25.9 \%$ of MSE, all being overpredicted, with $\mathrm{CCC}$ ranging from 0.34 to 0.55 . Because MiN and NANMN predictions were unbiased, the expectation was that predictions of postruminal flows of EAA should be similarly unbiased. The prediction errors could be driven by (1) missing dietary nutrient interactions, (2) incorrectly specified feed composition, (3) systematic bias in the AA composition of one or more protein fractions, or (4) poorer acid hydrolysis recovery in practice than reflected in the adjustment factors used. Except for the last, residuals could be expected to be correlated with the driving components. To test this hypothesis, several regression approaches were evaluated, including (1) residuals from each EAA prediction regressed on the corresponding predicted microbial, RUP, and endogenous EAA flows including an intercept term, (2) observed EAA prediction flows regressed on the corresponding predicted microbial, RUP, and endogenous EAA flows including an intercept term, (3) observed EAA prediction flows regressed on the predicted protein EAA flows without the inclusion of an intercept term, and (4) observed EAA prediction flows regressed on predicted RUP and MiCP EAA flows including an intercept.

Using the first regression approach, all 3 predicted protein flows were found to be correlated $(P<0.05)$ with the residuals for Arg, His, Ile, Lys, Thr, and Val. For Leu, only EndCP was found to be correlated with the residuals (Table 6). We found no significant correlations for Met or Phe. Because the majority of EAA had strong correlations between the protein flows and residuals, this suggests that the prediction errors may be caused by errors in the specification of the AA composition of those protein fractions. It is perhaps not surprising that RUP appeared to contribute to the prediction errors, as the passage of RUP is a function of multiple ingredients, which may not all be accurately predicted, and thus this system increases the chance of prediction problems (White et al., 2017a). Indeed, one or more ingredients may have poor predictions of RUP outflow, the latter being based on tabular values of rumen degradability. In addition, the AA composition of 
Table 5. Summary of evaluations of predictions of ruminal protein and EAA outflows, adjusted to reflect incomplete recovery from acid hydrolysis; observed values are as reported

\begin{tabular}{|c|c|c|c|c|c|c|c|c|}
\hline Variable $^{1}$ & Adjustment $^{2}$ & $\mathrm{~N}^{3}$ & $\begin{array}{l}\text { Observed } \\
\text { mean }\end{array}$ & $\begin{array}{l}\text { Predicted } \\
\text { mean }\end{array}$ & $\begin{array}{c}\mathrm{RMSE}^{4}{ }^{4} \\
\% \text { of observed mean }\end{array}$ & $\begin{array}{l}\text { Mean bias, } \\
\% \text { of MSE }\end{array}$ & $\begin{array}{l}\text { Slope bias, } \\
\% \text { of MSE }\end{array}$ & $\mathrm{CCC}^{6}$ \\
\hline NANMN, g/d & & 236 & 212 & 197 & 37.2 & $3.97^{*}$ & 0.02 & 0.35 \\
\hline dNDFRum, kg/d & & 125 & 4.02 & 4.10 & 21.2 & 0.86 & $6.81^{*}$ & 0.47 \\
\hline \multirow[t]{3}{*}{ Arg, g/d } & None & 229 & 120 & 138 & 31.8 & $23.9^{*}$ & $2.2^{*}$ & 0.44 \\
\hline & 1 & & & 119 & 25.4 & 0.0 & 0.3 & 0.55 \\
\hline & 4 & & & 117 & 27.1 & 0.4 & 0.8 & 0.50 \\
\hline \multirow[t]{5}{*}{ His, g/d } & None & 234 & 57.9 & 60.9 & 31.0 & $2.8^{*}$ & 0.6 & 0.44 \\
\hline & 1 & & & 57.5 & 28.8 & 0.1 & 0.0 & 0.50 \\
\hline & 2 & & & 55.6 & 29.1 & $1.9^{*}$ & 0.1 & 0.49 \\
\hline & 3 & & & 56.9 & 29.9 & 0.3 & 1.5 & 0.41 \\
\hline & 4 & & & 58.0 & 31.0 & 0.0 & 1.0 & 0.43 \\
\hline Ile, g/d & None & 234 & 122 & 138 & 31.4 & $16.1^{*}$ & 1.3 & 0.45 \\
\hline & 1 & & & 226 & 27.3 & 0.0 & 0.1 & 0.61 \\
\hline & 2 & & & 200 & 29.3 & $15.6^{*}$ & $3.5^{*}$ & 0.54 \\
\hline & 3 & & & 212 & 29.3 & $4.6^{*}$ & 1.6 & 0.51 \\
\hline & 4 & & & 215 & 29.0 & $3.1^{*}$ & 1.4 & 0.52 \\
\hline \multirow[t]{5}{*}{ Lys, g/d } & None & 232 & 158 & 190 & 40.6 & $25.9^{*}$ & $3.2^{*}$ & 0.34 \\
\hline & 1 & & & 157 & 31.8 & 0.0 & 1.2 & 0.43 \\
\hline & 2 & & & 144 & 33.1 & $7.1^{*}$ & $1.8^{*}$ & 0.40 \\
\hline & 3 & & & 151 & 33.4 & 1.6 & $4.8^{*}$ & 0.32 \\
\hline & 4 & & & 154 & 34.8 & 0.5 & 1.4 & 0.36 \\
\hline \multirow[t]{5}{*}{ Met, g/d } & None & 233 & 49.1 & 55.5 & 32.1 & $16.2^{*}$ & 1.4 & 0.53 \\
\hline & 1 & & & 48.6 & 32.0 & 0.1 & $1.9^{*}$ & 0.45 \\
\hline & 2 & & & 46.0 & 29.7 & $4.6^{*}$ & 0.4 & 0.59 \\
\hline & 3 & & & 46.4 & 29.6 & $3.5^{*}$ & 0.4 & 0.59 \\
\hline & 4 & & & 46.0 & 29.7 & $4.6^{*}$ & 0.4 & 0.59 \\
\hline Thr, g/d & 4 & & & 118 & 25.5 & $4.1^{*}$ & 0.3 & 0.55 \\
\hline \multirow[t]{5}{*}{ Val, g/d } & None & 234 & 140 & 152 & 30.6 & $7.6^{*}$ & 0.6 & 0.44 \\
\hline & 1 & & & 139 & 28.2 & 0.0 & 0.2 & 0.48 \\
\hline & 2 & & & 119 & 31.9 & $22.1^{*}$ & $1.9^{*}$ & 0.39 \\
\hline & 3 & & & 128 & 30.7 & $7.4^{*}$ & $4.6^{*}$ & 0.33 \\
\hline & 4 & & & 121 & 32.4 & $16.9^{*}$ & 0.0 & 0.37 \\
\hline
\end{tabular}

${ }^{1}$ NANMN = non-ammonia, non-microbial $\mathrm{N}$ flow $(\mathrm{g} / \mathrm{d}) ; \mathrm{MiN}=$ microbial $\mathrm{N}$ flow $(\mathrm{g} / \mathrm{d}) ; \mathrm{dStRum}=$ digestible starch in the rumen $(\mathrm{kg} / \mathrm{d}) ; \mathrm{dND}-$ FRum $=$ digestible NDF in the rumen $(\mathrm{kg} / \mathrm{d})$.

${ }^{2}$ None $=$ ruminal EAA outflows $(\mathrm{g} / \mathrm{d})$ as predicted by the model; $1=$ model predictions $(\mathrm{g} / \mathrm{d})$ adjusted using regressions of residual EAA flows on protein EAA flows including an intercept; $2=$ model predictions $(\mathrm{g} / \mathrm{d})$ adjusted using regressions of observed EAA flows on protein EAA flows including an intercept; $3=$ model predictions $(\mathrm{g} / \mathrm{d})$ adjusted using regressions of observed EAA flows on protein EAA flows excluding an intercept; 4 = model predictions (g/d) adjusted using regressions of observed EAA flows on RUP and microbial CP flows including an intercept.

${ }^{3} \mathrm{~N}=$ number of observations.

${ }^{4} \mathrm{RMSE}=$ root mean squared error (\% of observed mean).

${ }^{5} \mathrm{MSE}=$ mean squared error.

${ }^{6} \mathrm{CCC}=$ concordance correlation coefficient.

$* P \leq 0.05$. 


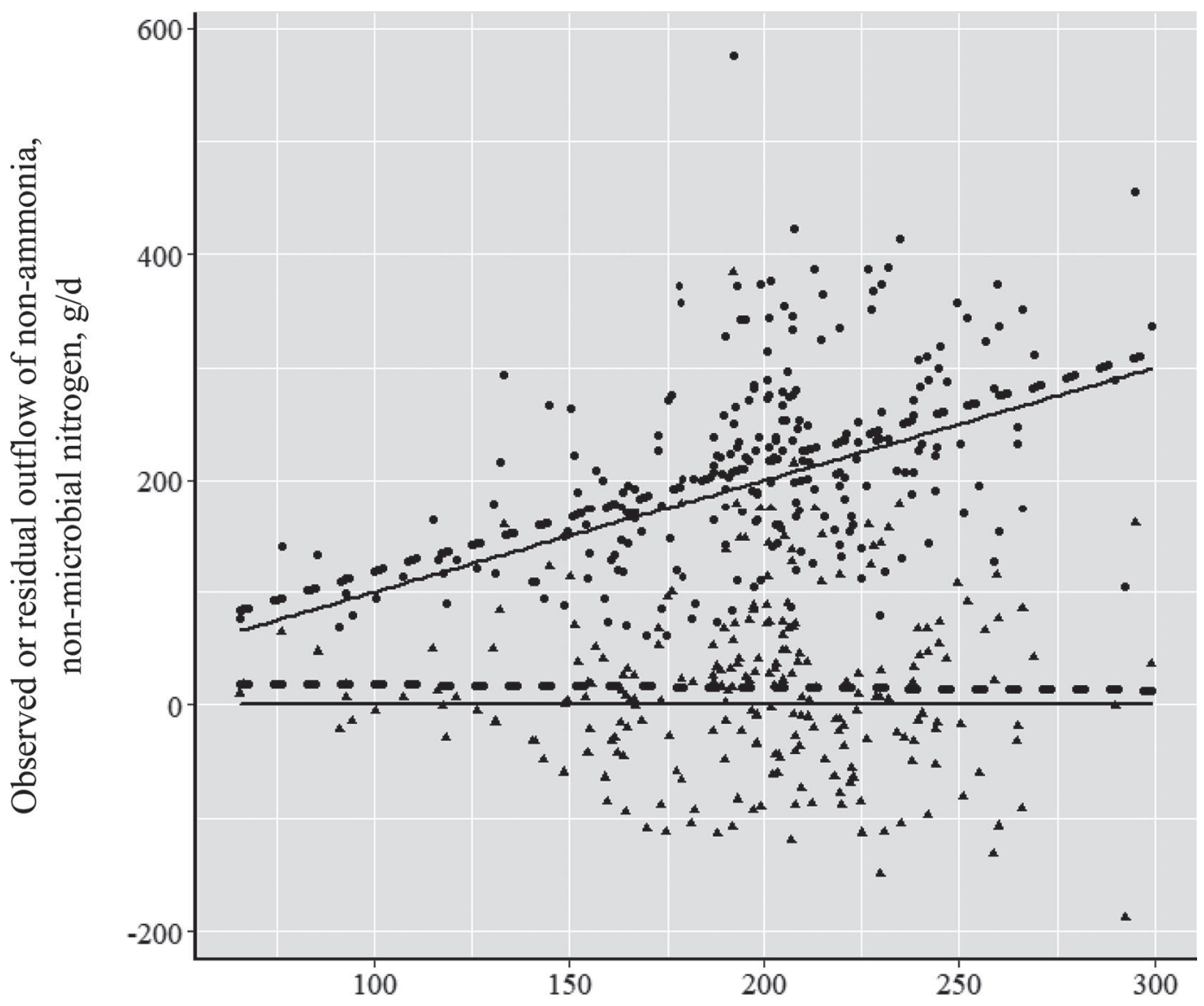

Predicted ruminal outflow of non-ammonia, non-microbial nitrogen, $\mathrm{g} / \mathrm{d}$

Figure 1. Predictions of ruminal outflow of non-ammonia, non-microbial nitrogen using Equation [10]. The solid lines represent unity, and the dashed line is the best-fit linear equation relating observed or residuals to predicted. Circles represent observed values, and triangles represent predicted values.

RUP was assumed to be similar to the AA composition of the feed ingredient, which is known to be false in some cases (Maxin et al., 2013), but not enough data are available to address this assumption. However, if these were the root causes of the problem, it seems more likely they would manifest as random variations, given the large range in diets used, and thus would not be correlated with RUP flow.

Endogenous protein composition may also contribute to prediction errors because of the very few observations of its AA composition (Lapierre et al., 2006). It is more surprising that MiCP flows were significantly correlated with the residuals, because the composition of MiCP has been well characterized and is thought to be fairly constant (Clark et al., 1992).

Even though the analyses indicated that all 3 protein flows were contributing to the prediction errors, the contribution of EndCP was predicted to be much greater than that of RUP or MiCP. This suggests that endogenous EAA composition or protein flow may be poorly specified. The bias-adjusted predictions reduced mean bias to less than 1\% of MSE and yielded CCC ranging from 0.43 to 0.61 . We discovered small but significant slope biases for Met $(P<0.05 ; 1.9 \%$ MSE) and Thr $(P<0.10 ; 1.6 \%$ MSE $)$. However, the results obtained from this regression approach were not biologically feasible. Most of the duodenal AA flow is comprised of RUP and MiCP, with EndCP representing typically less than $20 \%$ of the total duodenal flow (Lapierre et al., 2006), yet EndCP-based adjustments suggested by the residual analysis were larger than the actual duodenal flows, with partially offsetting negative adjustments associated with MiCP and RUP. This obviously is not reflective of any potential bias in the individual protein-based flows.

Using the second regression approach, where the 3 protein-driven EAA flows were regressed on observed EAA flows with an intercept term, resulted in signifi- 
cance for RUP and endogenous EAA flow for all AA flows excluding Met, which had significant terms for RUP and microbial flows. The resulting predictions resulted in mean bias $(P<0.05 ;>2 \%$ MSE) for all $\mathrm{AA}$ and slope bias for all AA except Arg, His, Met, and Phe $(P<0.05)$, yielding CCC ranging from 0.36 to 0.59 . As above, this approach resulted in biologically unfeasible solutions, with the majority of bias associated with EndCP flow and minimal contribution from the remaining proteins.

Using the third regression approach did not address all of the mean and slope biases for the majority of the AA $(P<0.005)$ and resulted in $\mathrm{CCC}$ ranging from 0.32 to 0.59 . Using this approach, His, Ile, Lys, and Val flow predictions were correlated with EndCP flows that were still several fold greater than the predicted flows for each protein, and thus this regression approach was not biologically feasible (Table 6 ).
A possible reason for EndCP being such a large driver in the regression approaches was its single input of DMI, which perhaps introduces less variation into the regression model than the more complicated MiTP and RUP equations. The final regression approach evaluated was performed using only RUP and MiCP terms against the observed AA flows and excluded the EndCP term. This approach yielded more biologically sensible parameters but still large adjustments, ranging from 0.5 to $0.9 \mathrm{~g}$ per day for RUP and 0.9 to $1.2 \mathrm{~g}$ per day for MiCP. Using this approach still resulted in significant mean bias for all EAA excluding Arg, His, and Lys $(P<0.05)$, with CCC ranging from 0.36 to 0.59 .

Evaluating the 4 methods used to adjust protein flows based purely on statistical performance, bias adjustment based on protein flow using EAA residuals as the regressor provided the best accuracy and precision (Figure 4). However, the adjustments are outside of

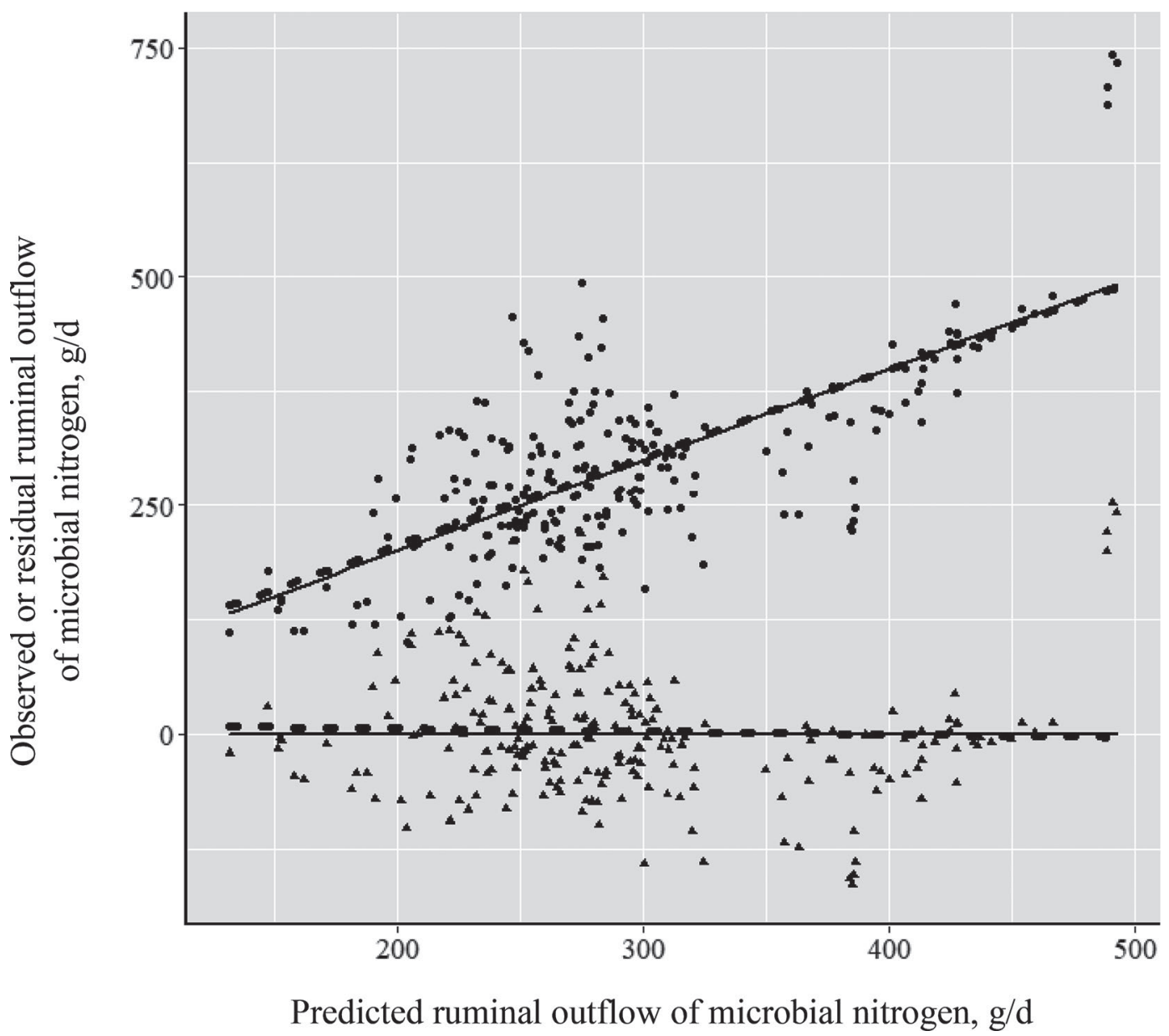

Figure 2. Predictions of ruminal outflow of microbial nitrogen using Equation [2]. The solid lines represent unity, and the dashed line is the best-fit linear equation relating observed or residuals to predicted. Circles represent observed values, and triangles represent predicted values. 

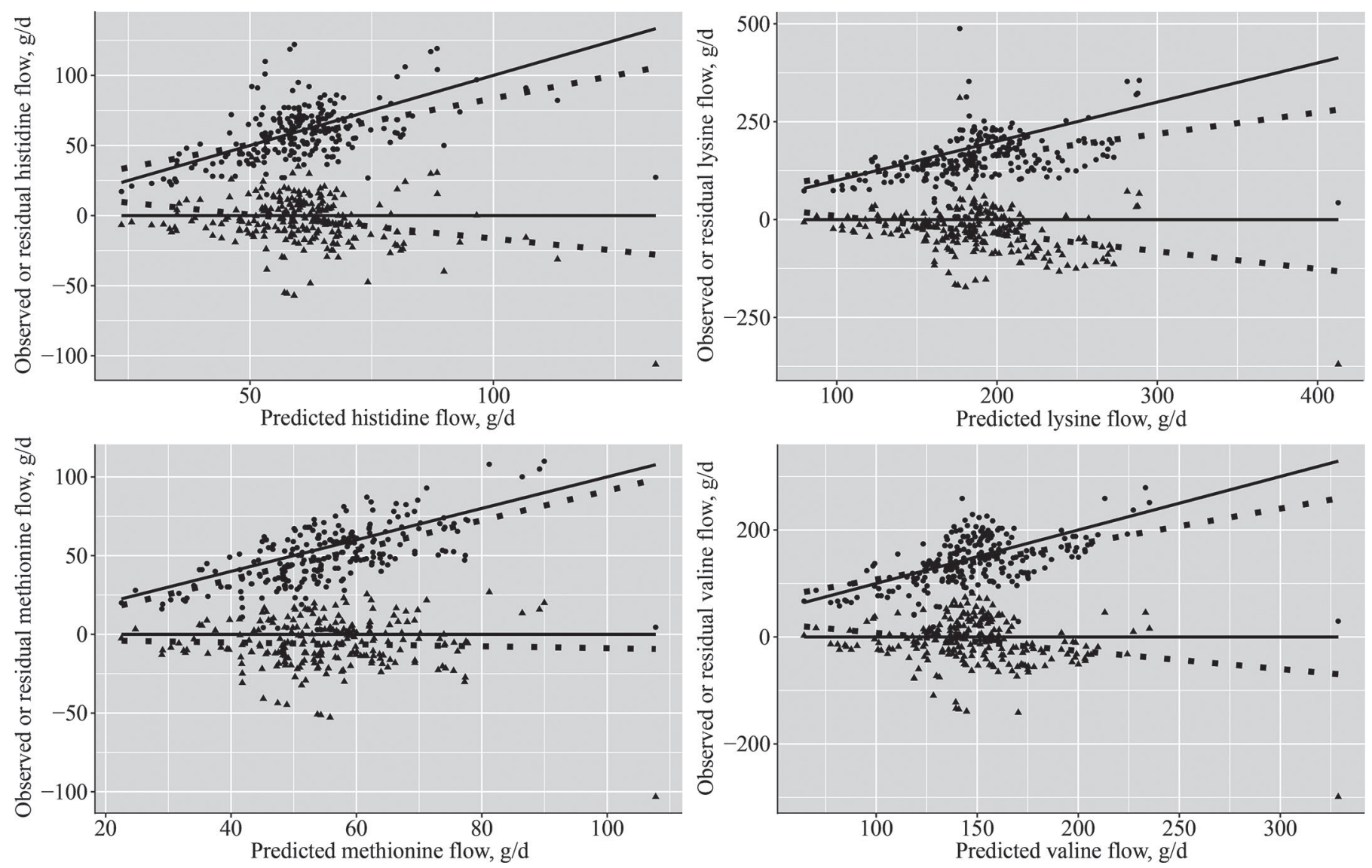

Figure 3. Duodenal EAA flows $(\mathrm{g} / \mathrm{d})$ as predicted by the model. The solid lines represent unity, and the dashed lines are the best-fit linear equations relating observed or residuals to predicted. Predicted values (triangles) were adjusted to reflect incomplete recovery from acid hydrolysis, to match the observed data (circles).

the likely range, suggesting that the problem is rooted in some aspect of the measurement. The generally low observed values, compared with predicted, suggest that the problem may be rooted in inadequate techniques when conducting the acid hydrolysis, resulting in generally lower recoveries than the values reported by Lapierre et al. (2016b) in the majority of laboratories. Such a conclusion is consistent with the observed residual errors. It also may explain the correlations with the protein flows. If recovery were, for example, $90 \%$ of the true values, the magnitude of the bias would be greater as true flows increased, which would present as a correlation with the predicted protein flows, assuming they are predicted without bias. Although we cannot test this hypothesis with the current data, it is the explanation that best aligns with the observed errors.

Given that Leu is predicted without bias and the mean biases for Val and Ile are relatively less than for other EAA, it seems more likely that the problem, if it is due to acid hydrolysis recovery, may be too much time or temperature. The opposite would be expected to result in incomplete recovery of the branched-chain AA. However, the relative error for Thr might be expected to be greater than for other EAA if that were the case, and such is not clearly evident. Recently, we have adopted a newer technique using much higher temperatures and a shorter duration (Walsh et al., 2014) and found that the recovery of EAA is improved. Although one cannot rule out other factors as the potential source of the bias, it is more difficult to conceive of other sources of variation that would cause the observed pattern in errors. More work is needed to determine the cause of the bias.

\section{CONCLUSIONS}

Based on the work herein, EAA flows can be predicted with moderate accuracy and precision from RUP, microbial, and endogenous CP flows if the observed data are corrected for losses during hydrolysis. The 
observed negative mean and slope bias may be due to prediction problems or under-reporting of true flows in the literature due to recovery problems.

\section{ACKNOWLEDGMENTS}

This research was supported by funding provided, in part, by a USDA NIFA grant (Award No: 20176701526539; Washington, USA); the Virginia Agricultural Experiment Station (Richmond, VA) and the Hatch Program of the National Institute of Food and Agriculture (Washington D.C., USA), U.S. Department of Agriculture; Agriculture and Agri-Food Canada
(Sherbrooke, QC, Canada), the College of Agriculture and Life Sciences Pratt Endowment at Virginia Tech (Blacksburg, VA); and Dairy Farmers of Canada, the Canadian Dairy Network, and the Canadian Dairy Commission under the Agri-Science Clusters Initiative (Ottawa, ON, Canada). A portion of this work was carried out and supported as an activity of the National Animal Nutrition Program (NANP) to provide enabling technologies, support, and shared resources to the research community. The NANP, a National Research Support Project (NRSP-9) of State Agricultural Experiment Stations, is funded from Hatch funds administered by the National Institute of Food and

Table 6. Results of backward elimination regression approaches of observed or residual EAA flows on predicted EAA flows (g/d) arising from RUP, microbial, and endogenous protein flows from the rumen ${ }^{1}$

\begin{tabular}{|c|c|c|c|c|c|c|c|c|}
\hline EAA & $\begin{array}{l}\text { Regression } \\
\text { approach }^{2}\end{array}$ & $\mathrm{~N}$ & $\mathrm{INT} \pm \mathrm{SE}$ & $\mathrm{RUP} \pm \mathrm{SE}$ & $\mathrm{MiCP} \pm \mathrm{SE}$ & EndCP $\pm \mathrm{SE}$ & $\mathrm{AICc}$ & $\mathrm{BIC}$ \\
\hline \multirow[t]{2}{*}{$\operatorname{Arg}$} & 1 & \multirow[t]{2}{*}{229} & $-55.2 \pm 21.3$ & $-0.5 \pm 0.1$ & $-0.7 \pm 0.3$ & $10.4 \pm 3.6$ & 1,987 & 2,007 \\
\hline & 4 & & NS & $0.5 \pm 0.1$ & $1.2 \pm 0.1$ & & 1,992 & 2,006 \\
\hline \multirow[t]{2}{*}{ His } & 1 & \multirow[t]{2}{*}{234} & $-30.8 \pm 11.8$ & $-0.2 \pm 0.1$ & $-1.1 \pm 0.4$ & $9.9 \pm 3.1$ & 1,763 & 1,783 \\
\hline & 2 & & $-28.7 \pm 10.7$ & $0.8 \pm 0.1$ & & $9.8 \pm 1.6$ & 1,761 & 1,778 \\
\hline \multirow[t]{4}{*}{ Ile } & 1 & \multirow[t]{4}{*}{234} & $-48.1 \pm 20.4$ & $-0.3 \pm 0.1$ & $-0.7 \pm 0.2$ & $11.5 \pm 3.9$ & 2,010 & 2,030 \\
\hline & 2 & & $-56.3 \pm 18.4$ & $0.5 \pm 0.1$ & & $15.6 \pm 1.9$ & 2,008 & 2,025 \\
\hline & 3 & & & $0.6 \pm 0.1$ & $0.5 \pm 0.2$ & $5.1 \pm 2.4$ & 2,013 & 2,030 \\
\hline & 4 & & NS & $0.6 \pm 0.1$ & $0.9 \pm 0.1$ & & 2,015 & 2,029 \\
\hline \multirow[t]{3}{*}{ Leu } & 1 & \multirow[t]{3}{*}{234} & $-85.6 \pm 35.8$ & & & $4.4 \pm 1.9$ & 2,319 & 2,333 \\
\hline & 2 & & $-135 \pm 35.5$ & $0.9 \pm 0.1$ & & $15.0 \pm 1.9$ & 2,318 & 2,335 \\
\hline & 3 & & & $0.9 \pm 0.1$ & $1.1 \pm 0.1$ & & 2,325 & 2,339 \\
\hline \multirow[t]{4}{*}{ Met } & 1 & \multirow[t]{4}{*}{233} & & & & & 1,583 & 1,593 \\
\hline & 2 & & $-10.5 \pm 5.2$ & $0.8 \pm 0.1$ & $1.2 \pm 0.1$ & & 1,583 & 1,600 \\
\hline & 3 & & & $0.7 \pm 0.1$ & $1.0 \pm 0.1$ & & 1,585 & 1,598 \\
\hline & 4 & & $-10.5 \pm 5.2$ & $0.8 \pm 0.1$ & $1.2 \pm 0.1$ & & 1,583 & 1,600 \\
\hline \multirow[t]{4}{*}{ Phe } & 1 & \multirow[t]{4}{*}{234} & & & & & 2,051 & 2,061 \\
\hline & 2 & & $-68.5 \pm 20.1$ & $0.7 \pm 0.1$ & & $16.3 \pm 2.0$ & 2,051 & 2,068 \\
\hline & 3 & & & $0.7 \pm 0.1$ & $1.0 \pm 0.1$ & & 2,054 & 2,068 \\
\hline & 4 & & NS & $0.7 \pm 0.1$ & $1.0 \pm 0.1$ & & 2,054 & 2,068 \\
\hline \multirow[t]{4}{*}{ Thr } & 1 & \multirow[t]{4}{*}{234} & $-50.9 \pm 18.8$ & $-0.3 \pm 0.1$ & $-0.5 \pm 0.2$ & $7.2 \pm 2.7$ & 1,974 & 1,994 \\
\hline & 2 & & $-65.2 \pm 17.1$ & $0.7 \pm 0.1$ & & $12.6 \pm 1.4$ & 1,975 & 1,992 \\
\hline & 3 & & & $0.8 \pm 0.1$ & $1.0 \pm 0.1$ & & 1,978 & 1,992 \\
\hline & 4 & & NS & $0.8 \pm 0.1$ & $1.0 \pm 0.1$ & & 1,978 & 1,992 \\
\hline \multirow[t]{2}{*}{ Val } & 1 & \multirow[t]{2}{*}{234} & $-56.1 \pm 23.3$ & & $-0.7 \pm 0.3$ & $9.0 \pm 3.4$ & 2,071 & 2,088 \\
\hline & 2 & & $-62.7 \pm 17.1$ & $0.1 \pm 0.8$ & & $1.4 \pm 12.4$ & 2,068 & 2,086 \\
\hline
\end{tabular}

\footnotetext{
${ }^{1}$ Terms were retained in the model at $P<0.05 . \mathrm{N}=$ number of observations; INT $=$ intercept; MiCP $=$ microbial $\mathrm{CP}$; EndCP $=$ endogenous $\mathrm{CP} ; \mathrm{AICc}=$ second-order Akaike information criterion; BIC $=$ Bayesian information criterion.

${ }^{2}$ Regression approaches: $1=$ model predictions (g/d) adjusted using regressions of residual EAA flows on protein EAA flows including an intercept; $2=$ model predictions $(\mathrm{g} / \mathrm{d})$ adjusted using regressions of observed EAA flows on protein EAA flows including an intercept; $3=$ model predictions $(\mathrm{g} / \mathrm{d})$ adjusted using regressions of observed EAA flows on protein EAA flows excluding an intercept; $4=$ model predictions $(\mathrm{g} / \mathrm{d})$ adjusted using regressions of observed EAA flows on RUP and MiCP flows including an intercept.
} 

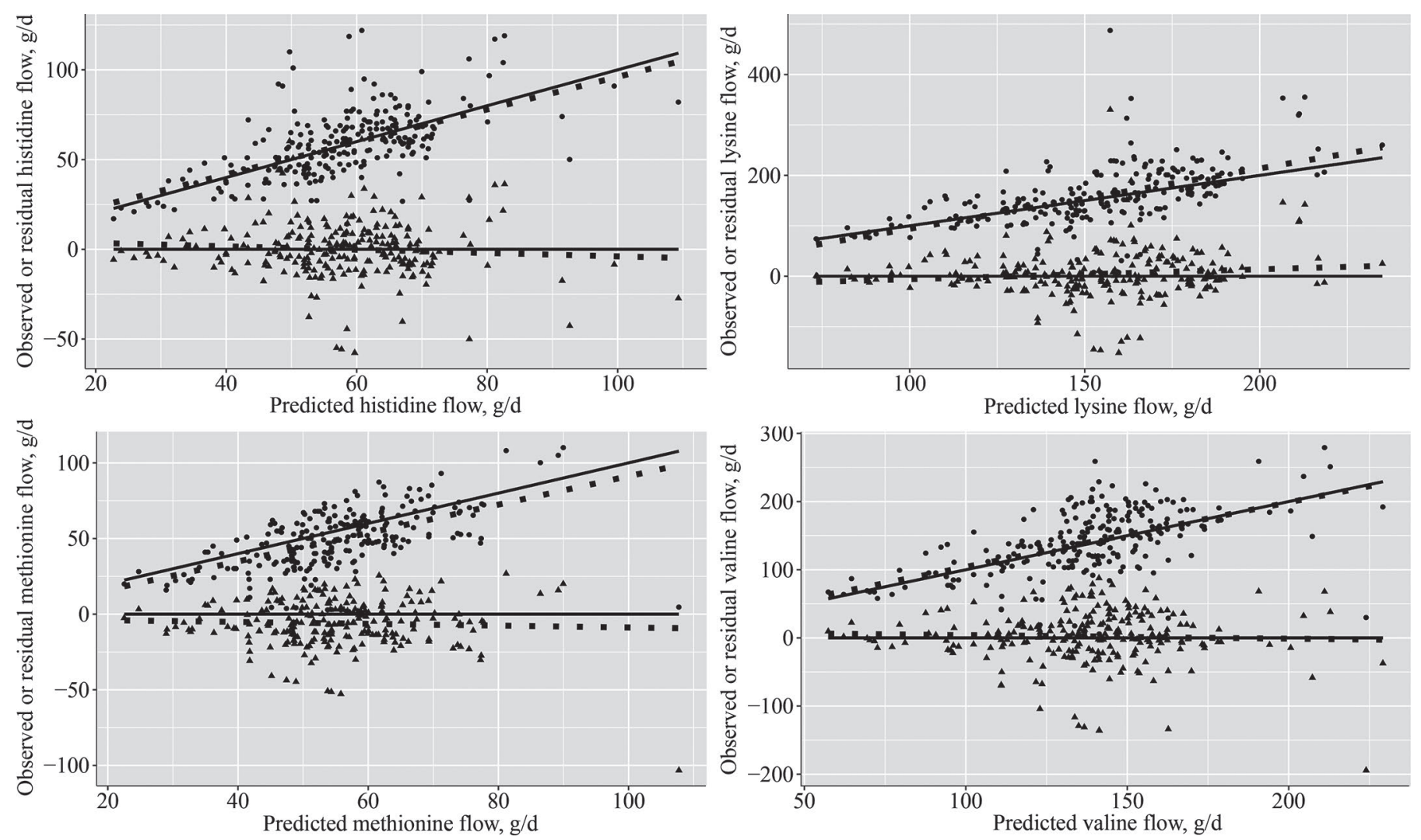

Figure 4. Predicted duodenal EAA flows (g/d) using bias adjustments based on the component proteins. The solid lines represent unity, and the dashed lines are the best-fit linear equations relating observed (circles) or residuals to predicted (triangles). All data are unadjusted for hydrolysis recovery.

Agriculture, US Department of Agriculture, Washington, DC. The NANP Coordinating Committee at the initiation of this work was composed of Gary Cromwell (University of Kentucky), Phillip Miller (University of Nebraska), Jack Odle (North Carolina State University), Mark Hanigan (Virginia Tech), William Weiss (The Ohio State University), Mary Beth Hall (USDA-ARS), Mike Galyean (Texas Tech), Todd Applegate (Purdue University), and Donald Beitz (Iowa State University). The NANP Modeling Subcommittee comprised Mark Hanigan (Virginia Tech), Brian Kerr (USDA/ARS), Ermias Kebreab (University of California-Davis), John McNamara (Washington State University), Luis Tedeschi (Texas A\&M University), Mike VandeHaar (Michigan State University), Nathalie Trottier (Michigan State University), and Roselina Angel (University of Maryland).

\section{REFERENCES}

Ahvenjärvi, S., A. Vanhatalo, and P. Huhtanen. 2002. Supplementing barley or rapeseed meal to dairy cows fed grass-red clover silage: I. Rumen degradability and microbial flow. J. Anim. Sci 80:2176-2187.

Aldrich, J. M., L. D. Muller, G. A. Varga, and L. C. Griel Jr.. 1993. Nonstructural carbohydrate and protein effects on rumen fermentation, nutrient flow, and performance of dairy cows. J. Dairy Sci. 76:1091-1105.

Appuhamy, J. A., J. R. Knapp, O. Becvar, J. Escobar, and M. D. Hanigan. 2011. Effects of jugular-infused lysine, methionine, and branched-chain amino acids on milk protein synthesis in high-producing dairy cows. J. Dairy Sci. 94:1952-1960.

Ardalan, M., M. Dehghan-Banadaky, and K. Rezayazdi. 2010. Milk yield persistency and its relationship with health problems in Holstein dairy cows supplemented with different levels of ruminally protected methionine and choline. Arch. Tierz. 3:266-276.

Armentano, L. E., S. J. Bertics, and G. A. Ducharme. 1997. Response of lactating cows to methionine or methionine plus lysine added to high protein diets based on alfalfa and heated soybeans. J. Dairy Sci. 80:1194-1199.

Armentano, L. E., T. A. Herrington, C. E. Polan, A. J. Moe, J. H. Herbein, and P. Umstadt. 1986. Ruminal degradation of dried brewers grains, wet brewers grains, and soybean meal. J. Dairy Sci. 69:2124-2133.

Arriola Apelo, S. I., A. L. Bell, K. Estes, J. Ropelewski, M. J. de Veth and M. D. Hanigan. 2014. Effects of reduced dietary protein and supplemental rumen-protected essential amino acids on the nitrogen efficiency of dairy cows. J. Dairy Sci. 97:5688-5699.

Bateman, H. G. II, J. H. Clark, and M. R. Murphy. 2005. Development of a system to predict feed protein flow to the small intestine of cattle. J. Dairy Sci. 88(Supp. 1):282-295. 
Bateman, H. G. II, M. D. Hanigan, and R. A. Kohn. 2008. Sensitivity of two metabolic models of dairy cattle digestion and metabolism to changes in nutrient content of diets. Anim. Feed Sci. Technol. 140:272-292.

Benchaar, C., C. Bayourthe, R. Monocoulon, and M. Vernay. 1991. Digestion ruminale et absorption intestinale des protéines du lupin extrudé chez la vache laitière. Reprod. Nutr. Dev. 31:655-665.

Benchaar, C., R. Moncoulon, C. Bayourthe, and M. Vernay. 1994a. Effects of a supply of raw or extruded white lupin seeds on protein digestion and amino acid absorption in dairy cows. J. Anim. Sci. $72: 492-501$

Benchaar, C., M. Vernay, C. Bayourthe, and R. Moncoulon. 1994b. Effects of extrusion of whole horse beans on protein digestion and amino acid absorption in dairy cows. J. Dairy Sci. 77:1360-1371.

Benefield, B. C., R. A. Patton, M. J. Stevenson, and T. R. Overton. 2009. Evaluation of rumen-protected methionine sources and period length on performance of lactating dairy cows within Latin squares. J. Dairy Sci. 92:4448-4455.

Bernard, J. K., P. T. Chandler, J. W. West, A. H. Parks, H. A. Amos, M. A. Froetschel, and D. S. Trammell. 2004. Effect of supplemental L-lysine- $\mathrm{HCl}$ and corn source on rumen fermentation and amino acid flow to the small intestine. J. Dairy Sci. 87:399-405.

Berthiaume, R., P. Dubreuil, M. Stevenson, B. W. McBride, and H. Lapierre. 2001. Intestinal disappearance and mesenteric and portal appearance of amino acids in dairy cows fed ruminally protected methionine. J. Dairy Sci. 84(Suppl. 1):194-203.

Berthiaume, R., M. C. Thivierge, R. A. Patton, P. Dubreuil, M. Stevenson, B. W. McBride, and H. Lapierre. 2006. Effect of ruminally protected methionine on splanchnic metabolism of amino acids in lactating dairy cows. J. Dairy Sci. 89:1621-1634.

Bibby, J., and H. Toutenburg. 1978. Improved estimation and prediction. Z. Angew. Math. Mech. 58:45-49.

Blackburn, S. 1968. Amino acid determination: Methods and techniques. M. Dekker, New York, NY.

Blauwiekel, R., S. Xu, J. H. Harrison, K. A. Loney, R. E. Riley, and M. C. Calhoun. 1997. Effect of whole cottonseed, gossypol, and ruminally protected lysine supplementation on milk yield and composition. J. Dairy Sci. 80:1358-1365.

Blum, J. W., R. M. Bruckmaier, and F. Jans. 1999. Rumen-protected methionine fed to dairy cows: Bioavailability and effects on plasma amino acid pattern and plasma metabolite and insulin concentrations. J. Dairy Sci. 82:1991-1998.

Boerman, J. P., J. de Souza, and A. L. Lock. 2017. Milk production and nutrient digestibility responses to increasing levels of stearic acid supplementation of dairy cows. J. Dairy Sci. 100:2729-2738.

Brito, A. F., and G. A. Broderick. 2006. Effect of varying dietary ratios of alfalfa silage to corn silage on production and nitrogen utilization in lactating dairy cows. J. Dairy Sci. 89:3924-3938.

Brito, A. F., G. A. Broderick, J. J. O. Colmenero, and S. M. Reynal. 2007a. Effects of feeding formate-treated alfalfa silage or red clover silage on omasal nutrient flow and microbial protein synthesis in lactating dairy cows. J. Dairy Sci. 90:1392-1404.

Brito, A. F., G. A. Broderick, and S. M. Reynal. 2007b. Effects of different protein supplements on omasal nutrient flow and microbial protein synthesis in lactating dairy cows. J. Dairy Sci. 90:18281841.

Brito, A. F., G. F. Tremblay, H. Lapierre, A. Bertrand, Y. Castonguay, G. Bélanger, R. Michaud, C. Benchaar, D. R. Ouellet, and R. Berthiaume. 2009. Alfalfa cut at sundown and harvested as baleage increases bacterial protein synthesis in late-lactation dairy cows. J. Dairy Sci. 92:1092-1107.

Broderick, G. A., and S. M. Reynal. 2009. Effect of source of rumendegraded protein on production and ruminal metabolism in lactating dairy cows. J. Dairy Sci. 92:2822-2834.

Broderick, G. A., M. J. Stevenson, and R. A. Patton. 2009. Effect of dietary protein concentration and degradability on response to rumen-protected methionine in lactating dairy cows. J. Dairy Sci. 92:2719-2728

Broderick, G. A., M. J. Stevenson, R. A. Patton, N. E. Lobos, and J. J. Olmos Colmenero. 2008. Effect of supplementing rumen-pro- tected methionine on production and nitrogen excretion in lactating dairy cows. J. Dairy Sci. 91:1092-1102.

Cameron, M. R., T. H. Klusmeyer, G. L. Lynch, J. H. Clark, and D. R. Nelson. 1991. Effects of urea and starch on rumen fermentation, nutrient passage to the duodenum, and performance of cows. J. Dairy Sci. 74:1321-1336.

Chen, Z. H., G. A. Broderick, N. D. Luchini, B. K. Sloan, and E. Devillard. 2011. Effect of feeding different sources of rumen-protected methionine on milk production and N-utilization in lactating dairy cows. J. Dairy Sci. 94:1978-1988.

Chibisa, G. E., D. A. Christensen, and T. Mutsvangwa. 2012. Effects of replacing canola meal as the major protein source with wheat dried distillers grains with solubles on ruminal function, microbial protein synthesis, omasal flow, and milk production in cows. J. Dairy Sci. 95:824-841.

Chilliard, Y., and M. Doreau. 1997. Influence of supplementary fish oil and rumen-protected methionine on milk yield and composition in dairy cows. J. Dairy Res. 64:173-179.

Chow, J. M., E. J. DePeters, and R. L. Baldwin. 1990. Effect of rumenprotected methionine and lysine on casein in milk when diets high in fat or concentrate are fed. J. Dairy Sci. 73:1051-1061.

Christensen, R. A., M. R. Cameron, T. H. Klusmeyer, J. P. Elliott, J. H. Clark, D. R. Nelson, and Y. Yu. 1993. Influence of amount and degradability of dietary protein on nitrogen utilization by dairy cows. J. Dairy Sci. 76:3497-3513.

Christensen, R. A., T. R. Overton, J. H. Clark, J. K. Drackley, D. R. Nelson, and S. A. Blum. 1996. Effects of dietary fat with or without nicotinic acid on nutrient flow to the duodenum of dairy cows. J. Dairy Sci. 79:1410-1424.

Clark, J. H., T. H. Klusmeyer, and M. R. Cameron. 1992. Microbial protein synthesis and flows of nitrogen fractions to the duodenum of dairy cows. J. Dairy Sci. 75:2304-2323.

Colmenero, J. J. O., and G. A. Broderick. 2006a. Effect of dietary crude protein concentration on milk production and nitrogen utilization in lactating dairy cows. J. Dairy Sci. 89:1704-1712.

Colmenero, J. J. O., and G. A. Broderick. 2006b. Effect of dietary crude protein concentration on ruminal nitrogen metabolism in lactating dairy cows. J. Dairy Sci. 89:1694-1703.

Cunningham, K. D., M. J. Cecava, and T. R. Johnson. 1993. Nutrient digestion, nitrogen, and amino acid flows in lactating cows fed soybean hulls in place of forage or concentrate. J. Dairy Sci. 76:3523-3535.

Cunningham, K. D., M. J. Cecava, and T. R. Johnson. 1994. Flows of nitrogen and amino acids in dairy cows fed diets containing supplemental feather meal and blood meal. J. Dairy Sci. 77:3666-3675.

Davidson, S., B. A. Hopkins, J. Odle, C. Brownie, V. Fellner, and L. W. Whitlow. 2008. Supplementing limited methionine diets with rumen-protected methionine, betaine, and choline in early lactation Holstein cows. J. Dairy Sci. 91:1552-1559.

de Souza, J., J. L. Garver, C. L. Preseault, and A. L. Lock. 2017. Short communication: Effects of prill size of a palmitic acid-enriched fat supplement on the yield of milk and milk components, and nutrient digestibility of dairy cows. J. Dairy Sci. 100:379-384.

Donkin, S. S., G. A. Varga, T. F. Sweeney, and L. D. Muller. 1989. Rumen-protected methionine and lysine: Effects on animal performance, milk protein yield, and physiological measures. J. Dairy Sci. 72:1484-1491.

Drackley, J. K., and J. P. Elliott. 1993. Milk composition, ruminal characteristics, and nutrient utilization in dairy cows fed partially hydrogenated tallow. J. Dairy Sci. 76:183-196.

Drackley, J. K., D. E. Grum, G. C. McCoy, and T. H. Klusmeyer. 1994. Comparison of three methods for incorporation of liquid fat into diets for lactating dairy cows. J. Dairy Sci. 77(Suppl. 5):13861398.

Elliott, J. P., J. K. Drackley, and D. J. Weigel. 1996. Digestibility and effects of hydrogenated palm fatty acid distillate in lactating dairy cows. J. Dairy Sci. 79(Suppl. 6):1031-1039.

Erasmus, L. J., P. M. Botha, and A. Kistner. 1992. Effect of yeast culture supplement on production, rumen fermentation, and duodenal nitrogen flow in dairy cows. J. Dairy Sci. 75:3056-3065. 
Erasmus, L. J., P. M. Botha, and H. H. Meissner. 1994. Effect of protein source on ruminal fermentation and passage of amino acids to the small intestine of lactating cows. J. Dairy Sci. 77:3655-3665.

Fanchone, A., P. Nozière, J. Portelli, B. Duriot, V. Largeau, and M. Doreau. 2013. Effects of nitrogen underfeeding and energy source on nitrogen ruminal metabolism, digestion, and nitrogen partitioning in dairy cows. J. Anim. Sci. 91:895-906.

Fox, D. G., L. O. Tedeschi, T. P. Tylutki, J. B. Russell, M. E. Van Amburgh, L. E. Chase, A. N. Pell, and T. R. Overton. 2004. The Cornell Net Carbohydrate and Protein System model for evaluating herd nutrition and nutrient excretion. Anim. Feed Sci. Technol. 112:29-78.

Giallongo, F., M. T. Harper, J. Oh, J. C. Lopes, H. Lapierre, R. A Patton, C. Parys, I. Shinzato, and A. N. Hristov. 2016. Effects of rumen-protected methionine, lysine, and histidine on lactation performance of dairy cows. J. Dairy Sci. 99:4437-4452.

Girard, C. L., H. Lapierre, J. J. Matte, and G. E. Lobley. 2005. Effects of dietary supplements of folic acid and rumen-protected methionine on lactational performance and folate metabolism of dairy cows. J. Dairy Sci. 88(Suppl. 2):660-670.

Guinard, J., and H. Rulquin. 1995. Effects of graded amounts of duodenal infusions of methionine on the mammary uptake of major milk precursors in dairy cows. J. Dairy Sci. 78:2196-2207.

Halmemies-Beauchet-Filleau, A., A. Vanhatalo, V. Toivonen, T. Heikkilä, M. R. F. Lee, and K. J. Shingfield. 2014. Effect of replacing grass silage with red clover silage on nutrient digestion, nitrogen metabolism, and milk fat composition in lactating cows fed diets containing a 60:40 forage-to-concentrate ratio. J. Dairy Sci. 97:3761-3776

Hanigan, M. D., J. A. Appuhamy, and P. Gregorini. 2013. Revised digestive parameter estimates for the Molly cow model. J. Dairy Sci. 96:3867-3885.

Higgs, R. J., L. E. Chase, D. A. Ross, and M. E. Van Amburgh. 2015 Updating the Cornell Net Carbohydrate and Protein System feed library and analyzing model sensitivity to feed inputs. J. Dairy Sci. 98:6340-6360.

INRA (Institut National de la Recherche Agronomique). 2018. INRA Feeding System for Ruminants. Wageningen Academic Publishers, Wageningen, the Netherlands.

Ipharraguerre, I. R., J. H. Clark, and D. E. Freeman. 2005a. Rumen fermentation and intestinal supply of nutrients in dairy cows fed rumen-protected soy products. J. Dairy Sci. 88:2879-2892.

Ipharraguerre, I. R., J. H. Clark, and D. E. Freeman. 2005b. Varying protein and starch in the diet of dairy cows. I. Effects on ruminal fermentation and intestinal supply of nutrients. J. Dairy Sci. $88: 2537-2555$.

Ipharraguerre, I. R., Z. Shabi, J. H. Clark, and D. E. Freeman. 2002. Ruminal fermentation and nutrient digestion by dairy cows fed varying amounts of soyhulls as a replacement for corn grain. J. Dairy Sci. 85:2890-2904.

Jenkins, T. C., and B. F. Jenny. 1989. Effect of hydrogenated fat on feed intake, nutrient digestion, and lactation performance of dairy cows. J. Dairy Sci. 72(Suppl. 9):2316-2324.

Jones-Endsley, J. M., M. J. Cecava, and T. R. Johnson. 1997. Effects of dietary supplementation on nutrient digestion and the milk yield of intensively grazed lactating dairy cows. J. Dairy Sci. 80:3283-3292

Joy, M. T., E. J. DePeters, J. G. Fadel, and R. A. Zinn. 1997. Effects of corn processing on the site and extent of digestion in lactating cows. J. Dairy Sci. 80:2087-2097.

King, K. J., J. T. Huber, M. Sadik, W. G. Bergen, A. L. Grant, and V. L. King. 1990. Influence of dietary protein sources on the amino acid profiles available for digestion and metabolism in lactating cows. J. Dairy Sci. 73:3208-3216.

Klusmeyer, T. H., G. L. Lynch, J. H. Clark, and D. R. Nelson. 1991a Effects of calcium salts of fatty acids and protein source on ruminal fermentation and nutrient flow to duodenum of cows. J. Dairy Sci. 74:2206-2219.

Klusmeyer, T. H., G. L. Lynch, J. H. Clark, and D. R. Nelson. 1991b. Effects of calcium salts of fatty acids and proportion of forage in diet on ruminal fermentation and nutrient flow to duodenum of cows. J. Dairy Sci. 74:2220-2232.

Klusmeyer, T. H., R. D. McCarthy Jr., J. H. Clark, and D. R. Nelson. 1990. Effects of source and amount of protein on ruminal fermentation and passage of nutrients to the small intestine of lactating cows. J. Dairy Sci. 73:3526-3537.

Korhonen, M., A. Vanhatalo, and P. Huhtanen. 2002. Effect of protein source on amino acid supply, milk production, and metabolism of plasma nutrients in dairy cows fed grass silage. J. Dairy Sci. 85:3336-3351.

Kowalski, Z. M., P. M. Pisulewski, and M. Görgülü. 2003. Effects of protected methionine and variable energy supply on lactational responses in dairy cows fed grass silage-based diets. J. Anim. Feed Sci. 12:451-464.

Kowalski, Z. M., P. M. Pisulewski, and M. Spanghero. 1999. Effects of calcium soaps of rapeseed fatty acids and protected methionine on milk yield and composition in dairy cows. J. Dairy Res. $66: 475-487$

Kröber, T. F., M. Kreuzer, M. Senn, W. Langhans, and F. Sutter. 2000. Lactational and metabolic effects in cows of lysine and methionine added to a ration deficient according to the I.N.R.A. method. Arch. Tierernahr. 53:375-394.

Kudrna, V., J. Illek, M. Marounek, and A. Nguyen Ngoc. 2009. Feeding ruminally protected methionine to pre- and postpartum dairy cows: Effect on milk performance, milk composition and blood parameters. Czech J. Anim. Sci. 54:395-402.

Kuznetsova, A., P. B. Brockhoff, and R. H. B. Christensen. 2017. lmerTest Package: Tests in linear mixed effects model. J. Stat. Softw. 82:1-26.

Lapierre, H., M. D. Hanigan, and D. R. Ouellet. 2016a. Estimation of duodenal endogenous protein flow in dairy cattle: A regression approach. In Proc. energy and protein metabolism and nutrition. EAAP publication. Wageningen Academic Publishers, the Netherlands. In press.

Lapierre, H., D. R. Ouellet, R. Martineau, and J. W. Spek. 2016b. Key roles of amino acids in cow performance and metabolism-Considerations for defining amino acid requirements. In Cornell Nutrition Conference, Syracuse, NY. Cornell University, Ithaca, NY.

Lapierre, H., D. Pacheco, R. Berthiaume, D. R. Ouellet, C. G. Schwab, P. Dubreuil, G. Holtrop, and G. E. Lobley. 2006. What is the true supply of amino acids for a dairy cow? J. Dairy Sci. 89(Suppl. 1):E1-E14.

Lara, A., G. D. Mendoza, L. Landois, R. Barcena, M. T. SánchezTorres, R. Rojo, J. Ayala, and S. Vega. 2006. Milk production in Holstein cows supplemented with different levels of ruminally protected methionine. Livest. Sci. 105:105-108.

Leonardi, C., M. Stevenson, and L. E. Armentano. 2003. Effect of two levels of crude protein and methionine supplementation on performance of dairy cows. J. Dairy Sci. 86:4033-4042.

Lin, L. I.-K. 1989. A concordance correlation coefficient to evaluate reproducibility. Biometrics 45:255-268.

Loor, J. J., J. H. Herbein, and T. C. Jenkins. 2002. Nutrient digestion, biohydrogenation, and fatty acid profiles in blood plasma and milk fat from lactating Holstein cows fed canola oil or canolamide. Anim. Feed Sci. Technol. 97:65-82.

Loor, J. J., K. Ueda, A. Ferlay, Y. Chilliard, and M. Doreau. 2004 Biohydrogenation, duodenal flow, and intestinal digestibility of trans fatty acids and conjugated linoleic acids in response to dietary forage:concentrate ratio and linseed oil in dairy cows. J. Dairy Sci. 87:2472-2485.

Lynch, G. L., T. H. Klusmeyer, M. R. Cameron, J. H. Clark, and D. R. Nelson. 1991. Effects of somatotropin and duodenal infusion of amino acids on nutrient passage to duodenum and performance of dairy cows. J. Dairy Sci. 74:3117-3127.

Mabjeesh, S. J., A. Arieli, I. Bruckental, S. Zamwell, and H. Tagari. 1996. Effect of type of protein supplementation on duodenal amino acid flow and absorption in lactating dairy cows. J. Dairy Sci. 79:1792-1801.

Mabjeesh, S. J., A. Arieli, I. Bruckental, S. Zamwell, and H. Tagari. 1997. Effect of ruminal degradability of crude protein and non- 
structural carbohydrates on the efficiency of bacterial crude protein synthesis and amino acid flow to the abomasum of dairy cows. J. Dairy Sci. 80:2939-2949.

Madsen, J. 1986. Influence of feeding level on digestion and protein passage to the duodenum in cows fed high concentrate diets. Acta Agric. Scand. 36:275-285.

Mansfield, H. R., and M. D. Stern. 1994. Effects of soybean hulls and lignosulfonate-treated soybean meal, on ruminal fermentation in lactating dairy cows. J. Dairy Sci. 77:1070-1083.

Maxin, G., D. R. Ouellet, and H. Lapierre. 2013. Ruminal degradability of dry matter, crude protein, and amino acids in soybean meal, canola meal, corn, and wheat dried distillers grains. J. Dairy Sci. 96:5151-5160.

McCarthy, R. D. Jr., T. H. Klusmeyer, J. L. Vicini, J. H. Clark, and D. R. Nelson. 1989. Effects of source of protein and carbohydrate on ruminal fermentation and passage of nutrients to the small intestine of lactating cows. J. Dairy Sci. 72:2002-2016.

Merchen, N. R., and L. D. Satter. 1983. Changes in nitrogenous compounds and sites of digestion of alfalfa harvested at different moisture contents. J. Dairy Sci. 66:789-801.

Misciatteilli, L., V. F. Kristensen, M. Vestergaard, M. R. Weisbjerg, K. Sejrsen, and T. Hvelplund. 2003. Milk production, nutrient utilization, and endocrine responses to increased postruminal lysine and methionine supply in dairy cows. J. Dairy Sci. 86:275-286.

Moller, P. D. 1985. Results of grass silage based rations on the nitrogen absorption in the gastro-intestinal tract of dairy cows applied in the Nordic Protein Evaluation System. Acta Agric. Scand. Suppl $25,49-63$.

Murphy, M., P. Udén, D. L. Palmquist, and H. Wiktorsson. 1987. Rumen and total diet digestibilities in lactating cows fed diets containing full-fat rapeseed. J. Dairy Sci. 70:1572-1582.

Narasimhalu, P., E. Teller, M. Vanbelle, M. Foulon, and F. Dasnoy. 1989. Apparent digestibility of nitrogen in rumen and whole tract of Friesian cattle fed direct-cut and wilted grass silages. J. Dairy Sci. 72:2055-2061.

NRC (National Research Council). 2001. Nutrient Requirements of Dairy Cattle. 7th ed. Natl. Acad. Press, Washington, DC.

O'Mara, F. P., J. J. Murphy, and M. Rath. 1998. Effect of amount of dietary supplement and source of protein on milk production, ruminal fermentation, and nutrient flows in dairy cows. J. Dairy Sci. 81:2430-2439.

O'Mara, F. P., G. K. Stakelum, P. Dillon, J. J. Murphy, and M. Rath. 1997. Rumen fermentation and nutrient flows for cows fed grass and grass supplemented with molassed beet pulp pellets. J. Dairy Sci. 80:2466-2474.

Offer, N. W., R. E. Agnew, B. R. Cottrill, D. I. Givens, T. W. J. Keady, C. S. Mayne, C. Rymer, T. Yan, J. France, D. E. Beever, C. Thomas, P. C. Garnsworthy, and J. Wiseman. 2002. Feed into milk-An applied feeding model coupled with a new system of feed characterisation Pages 167-194 in Recent Advances in Animal Nutrition. P. C. Garnsworthy, J. Wiseman, D. J. A. Cole, and J. Wiseman, ed. Nottingham University Press, Nottingham, UK.

Ohajuruka, O. A., Z. Wu, and D. L. Palmquist. 1991. Ruminal metabolism, fiber, and protein digestion by lactating cows fed calcium soap or animal-vegetable fat. J. Dairy Sci. 74:2601-2609.

Oliveira, J. S., J. T. Huber, J. M. Simas, C. B. Theurer, and R. S. Swingle. 1995. Effect of sorghum grain processing on site and extent of digestion of starch in lactating dairy cows. J. Dairy Sci. 78:1318-1327.

Ordway, R. S., S. E. Boucher, N. L. Whitehouse, C. G. Schwab, and B. K. Sloan. 2009. Effects of providing two forms of supplemental methionine to periparturient Holstein dairy cows on feed intake and lactational performance. J. Dairy Sci. 92:5154-5166.

Orskov, E. R., N. A. MacLeod, and D. J. Kyle. 1986. Flow of nitrogen from the rumen and abomasum in cattle and sheep given proteinfree nutrients by intragastric infusion. Br. J. Nutr. 56:241-248.

Overton, T. R., M. R. Cameron, J. P. Elliottt, J. H. Clark, and D. R. Nelson. 1995. Ruminal fermentation and passage of nutrients to the duodenum of lactating cows fed mixture of corn and barley. J. Dairy Sci. 78:1981-1998.
Overton, T. R., L. S. Emmert, and J. H. Clark. 1998. Effects of source of carbohydrate and protein and rumen-protected methionine on performance of cows. J. Dairy Sci. 81:221-228.

Overton, T. R., D. W. Lacount, T. M. Cicela, and J. H. Clark. 1996 Evaluation of a ruminally protected methionine product for lactating dairy cows. J. Dairy Sci. 79:631-638.

Pacheco, D., R. A. Patton, C. Parys, and H. Lapierre. 2012. Ability of commercially available dairy ration programs to predict duodenal flows of protein and essential amino acids in dairy cows. J. Dairy Sci. 95:937-963.

Palmquist, D. L. 1991. Influence of source and amount of dietary fat on digestibility in lactating cows. J. Dairy Sci. 74:1354-1360.

Palmquist, D. L., M. R. Weisbjerg, and T. Hvelplund. 1993. Ruminal, intestinal, and total digestibilities of nutrients in cows fed diets high in fat and undegradable protein. J. Dairy Sci. 76:1353-1364.

Pantoja, J., J. L. Firkins, M. L. Eastridge, and B. L. Hull. 1996. Fatty acid digestion in lactating dairy cows fed fats varying in degree of saturation and different fiber sources. J. Dairy Sci. 79(Suppl. 4):575-584.

Papas, A. M., C. J. Sniffen, and T. V. Muscato. 1984a. Effectiveness of rumen-protected methionine for delivering methionine postruminally in dairy cows. J. Dairy Sci. 67:545-552.

Papas, A. M., J. L. Vicini, J. H. Clark, and S. Peirce-Sandner. 1984b. Effect of rumen-protected methionine on plasma free amino acids and production by dairy cows. J. Nutr. 114:2221-2227.

Pena, F., H. Tagari, and L. D. Satter. 1986. The effect of heat treatment of whole cottonseed on site and extent of protein digestion in dairy cows. J. Anim. Sci. 62:1423-1433.

Piantoni, P. A. L. Lock, and M. S. Allen. 2013. Palmitic acid increased yields of milk and milk fat and nutrient digestibility across production level of lactating cows. J. Dairy Sci. 96:7143-7154.

Piantoni, P., A. L. Lock, and M. S. Allen. 2015. Milk production responses to dietary stearic acid vary by production level in dairy cattle. J. Dairy Sci. 98:1938-1949.

Pisulewski, P. M., Z. M. Kowalski, and M. Görgülü. 2002. Lactational responses to ruminally-protected methionine in cows fed a lowprotein grass silage-based diet. J. Anim. Feed Sci. 11:189-203.

Pisulewski, P. M., H. Rulquin, J. L. Peyraud, and R. Verite. 1996. Lactational and systemic responses of dairy cows to postruminal infusions of increasing amounts of methionine. J. Dairy Sci. 79:1781-1791.

Polan, C. E., K. A. Cummins, C. J. Sniffen, T. V. Muscato, J. L. Vicini, B. A. Crooker, J. H. Clark, D. G. Johnson, D. E. Otterby, B. Guillaume, L. D. Muller, G. A. Varga, R. A. Murray, and S B. Peirce-Sandner. 1991. Responses of dairy cows to supplemental rumen-protected forms of methionine and lysine. J. Dairy Sci. 74:2997-3013.

Prange, R. W., M. D. Stern, N. A. Jorgensen, and L. D. Satter. 1984. Site and extent of protein digestion in lactating cows fed alfalfa silage or baled alfalfa hay. J. Dairy Sci. 67:2308-2314.

Preynat, A., H. Lapierre, M. C. Thivierge, M. F. Palin, J. J. Matte, A. Desrochers, and C. L. Girard. 2009. Influence of methionine supply on the response of lactational performance of dairy cows to supplementary folic acid and vitamin B12. J. Dairy Sci. 92:1685-1695.

Price, S. G., L. D. Satter, and N. A. Jorgensen. 1988. Dehydrated alfalfa in dairy cow diets. J. Dairy Sci. 71:727-736.

Pruekvimolphan, S., and R. R. Grummer. 2001. Lactation responses to sulfur-containing amino acids from feather meal or rumen-protected methionine. J. Dairy Sci. 84:2515-2522.

Putnam, D. E., C. G. Schwab, M. T. Socha, N. L. Whitehouse, N. A. Kierstead, and B. D. Garthwaite. 1997. Effect of yeast culture in the diets of early lactation dairy cows on ruminal fermentation and passage of nitrogen fractions and amino acids to the small intestine. J. Dairy Sci. 80:374-384.

R Core Team. 2015. R: A Language and Environment for Statistical Computing. R Foundation for Statistical Computing, Vienna, Austria.

Rees, M. W. 1946. The estimation of threonine and serine in proteins. Biochem. J. 40:632-640. 
Reynal, S. M., and G. A. Broderick. 2003. Effects of feeding dairy cows protein supplements of varying ruminal degradability. J. Dairy Sci. $86: 835-843$.

Reynal, S. M., G. A. Broderick, and C. Bearzi. 2005. Comparison of four markers for quantifying microbial protein flow from the rumen of lactating dairy cows. J. Dairy Sci. 88:4065-4082.

Reynal, S. M., I. R. Ipharraguerre, M. Liñeiro, A. F. Brito, G. A. Broderick, and J. H. Clark. 2007. Omasal flow of soluble proteins, peptides, and free amino acids in dairy cows fed diets supplemented with proteins of varying ruminal degradabilities. J. Dairy Sci. 90:1887-1903.

Rico, D. E., Y. Ying, and K. J. Harvatine. 2014. Effect of a highpalmitic acid fat supplement on milk production and apparent total-tract digestibility in high- and low-milk yield dairy cows. J. Dairy Sci. 97:3739-3751.

Robinson, P. H. 1997. Modifying duodenal flow of amino acids by manipulation of dietary protein sources. Can. J. Anim. Sci. 77:241251.

Robinson, P. H., W. Chalupa, C. J. Sniffen, W. E. Julien, H. Sato, T. Fujieda, T. Ueda, and H. Suzuki. 2000. Influence of abomasal infusion of high levels of lysine or methionine, or both, on ruminal fermentation, eating behavior, and performance of lactating dairy cows. J. Anim. Sci. 78:1067-1077.

Robinson, P. H., G. R. Khorasani, and J. J. Kennelly. 1994. Forestomach and whole tract digestion in lactating dairy cows fed canola meal treated with variable levels of acetic acid. J. Dairy Sci. 77:552-559.

Rogers, J. A., U. Krishnamoorthy, and C. J. Sniffen. 1987. Plasma amino acids and milk protein production by cows fed rumen-protected methionine and lysine. J. Dairy Sci. 70:789-798.

Roman-Garcia, Y., R. R. White, and J. L. Firkins. 2016. Meta-analysis of postruminal microbial nitrogen flows in dairy cattle. I. Derivation of equations. J. Dairy Sci. 99:7918-7931.

Rulquin, H., and L. Delaby. 1997. Effects of the energy balance of dairy cows on lactational responses to rumen-protected methionine. J. Dairy Sci. 80:2513-2522.

Rulquin, H., B. Graulet, L. Delaby, and J. C. Robert. 2006. Effect of different forms of methionine on lactational performance of dairy cows. J. Dairy Sci. 89:4387-4394.

Samuelson, D. J., S. K. Denise, R. Roffler, R. L. Ax, D. V. Armstrong, and D. F. Romagnolo. 2001. Response of Holstein and Brown Swiss cows fed alfalfa hay-based diets to supplemental methionine at two stages of lactation. J. Dairy Sci. 84:917-928.

Santos, K. A., M. D. Stern, and L. D. Satter. 1984. Protein degradation in the rumen and amino acid absorption in the small intestine of lactating dairy cattle fed various protein sources. J. Anim. Sci. $58: 244-255$.

Schwab, C. G., C. K. Bozak, N. L. Whitehouse, and M. M. A. Mesbah. 1992a. Amino acid limitation and flow to duodenum at four stages of lactation. 1. Sequence of lysine and methionine limitation. J. Dairy Sci. 75:3486-3502.

Schwab, C. G., C. K. Bozak, N. L. Whitehouse, and V. M. Olson 1992b. Amino acid limitation and flow to the duodenum at four stages of lactation. 2. Extent of lysine limitation. J. Dairy Sci. 75:3503-3518

Simas, J. M., J. T. Huber, C. B. Theurer, K. H. Chen, F. A. P. Santos, and Z. Wu. 1997. Influence of fat source and sorghum grain treatment on performance and digestibilities of high yielding dairy cows. J. Dairy Sci.80:2907-2912.

Simas, J. M., J. T. Huber, C. B. Theurer, K. H. Chen, F. A. P. Santos, and Z. Wu. 1998. Influence of sorghum grain processing on performance and nutrient digestibilities in dairy cows fed varying concentrations of fat. J. Dairy Sci. 81:1966-1971.

Socha, M. T., D. E. Putnam, B. D. Garthwaite, N. L. Whitehouse, N. A. Kierstead, C. G. Schwab, G. A. Ducharme, and J. C. Robert. 2005. Improving intestinal amino acid supply of pre- and postpartum dairy cows with rumen-protected methionine and lysine. J. Dairy Sci. 88:1113-1126.

Soder, K. J., and L. A. Holden. 1999. Lymphocyte proliferation response of lactating dairy cows fed varying concentrations of rumen-protected methionine. J. Dairy Sci. 82:1935-1942.
Sok, M., D. R. Ouellet, J. L. Firkins, D. Pellerin, and H. Lapierre 2017. Amino acid composition of rumen bacteria and protozoa in cattle. J. Dairy Sci. 100:5241-5249.

St-Pierre, N. R. 2003. Reassessment of biases in predicted nitrogen flows to the duodenum by NRC 2001. J. Dairy Sci. 86:344-350.

Stern, M. D., L. M. Rode, R. W. Prange, and R. H. Stauffacher. 1983. Ruminal protein degradation of corn gluten meal in lactating dairy cattle fitted with duodenal T-type cannulae. J. Anim. Sci. 56:194-205.

Stern, M. D., K. A. Santos, and L. D. Satter. 1985. Protein degradation in rumen and amino acid absorption in small intestine of lactating dairy cattle fed heat-treated whole soybeans. J. Dairy Sci. $68: 45-56$

Tamminga, S., W. M. Van Straalen, A. P. J. Subnel, R. G. M. Meijer, A. Steg, C. J. G. Wever, and M. C. Blok. 1994. The Dutch protein evaluation system: The DVE/OEB-system. Livest. Prod. Sci. 40:139-155.

Teller, E., M. Vanbelle, M. Foulon, G. Collignon, and B. Matatu. 1992 Nitrogen metabolism in rumen and whole digestive tract of lactating dairy cows fed grass silage. J. Dairy Sci. 75:1296-1304.

Tran, H., A. Schlageter-Tello, A. Caprez, P. S. Miller, M. B. Hall, W P. Weiss, and P. J. Kononoff. 2020. Development of feed composition tables using a statistical screening procedure. J. Dairy Sci. https://doi.org/10.3168/jds.2019-16702.

Van Vuuren, A. M., F. Krol-Kramer, R. A. Van der Lee, and H. Corbijn. 1992. Protein digestion and intestinal amino acids in dairy cows fed fresh Lolium perenne with different nitrogen contents. J. Dairy Sci. 75:2215-2225.

Vanhatalo, A., P. Huhtanen, V. Toivonen, and T. Varvikko. 1999 Response of dairy cows fed grass silage diets to abomasal infusions of histidine alone or in combinations with methionine and lysine. J. Dairy Sci. 82:2674-2685.

Vanhatalo, A., K. Kuoppala, S. Ahvenjärvi, and M. Rinne. 2009. Effects of feeding grass or red clover silage cut at two maturity stages in dairy cows. 1. Nitrogen metabolism and supply of amino acids. J. Dairy Sci. 92:5620-5633.

Varvikko, T., A. Vanhatalo, T. Jalava, and P. Huhtanen. 1999. Lactation and metabolic responses to graded abomasal doses of methionine and lysine in cows fed grass silage diets. J. Dairy Sci 82:2659-2673.

Volden, H. 1999. Effects of level of feeding and ruminally undegraded protein on ruminal bacterial protein synthesis, escape of dietary protein, intestinal amino acid profile, and performance of dairy cows. J. Anim. Sci. 77:1905-1918.

Volden, H. 2011. NorFor-The Nordic feed evaluation system. No. 130 Wageningen Academic Publishers, Wageningen, the Netherlands.

Walsh, R. G., S. He, and C. T. Yarnes. 2014. Compound-specific delta13C and delta15N analysis of amino acids: A rapid, chloroformate-based method for ecological studies. Rapid Commun. Mass Spectrom. 28:96-108.

Waltz, D. M., M. D. Stern, and D. J. Illg. 1989. Effect of ruminal protein degradation of blood meal and feather meal on the intestinal amino acid supply to lactating cows. J. Dairy Sci. 72:1509-1518.

Weisbjerg, R. C. F. Børsting, and T. Hvelplund. 1992. The influence of tallow on rumen metabolism, microbial biomass synthesis and fatty acid composition of bacteria and protozoa. Acta Agric. Scand. A Anim. Sci. 42:138-147.

Weiss, W. P., and D. J. Wyatt. 2004. Digestible energy values of diets with different fat supplements when fed to lactating dairy cows. J. Dairy Sci. 87(Suppl. 5):1446-1454

White, R. R., Y. Roman-Garcia, and J. L. Firkins. 2016. Meta-analysis of postruminal microbial nitrogen flows in dairy cattle. II. Approaches to and implications of more mechanistic prediction. J. Dairy Sci. 99:7932-7944.

White, R. R., Y. Roman-Garcia, J. L. Firkins, P. Kononoff, M. J. VandeHaar, H. Tran, T. McGill, R. Garnett, and M. D. Hanigan. 2017a. Evaluation of the National Research Council (2001) dairy model and derivation of new prediction equations. 2. Rumen degradable and undegradable protein. J. Dairy Sci. 100:3611-3627.

White, R. R., Y. Roman-Garcia, J. L. Firkins, M. J. VandeHaar, L. E. Armentano, W. P. Weiss, T. McGill, R. Garnett, and M. D. Hani- 
gan. 2017b. Evaluation of the National Research Council (2001) dairy model and derivation of new prediction equations. 1. Digestibility of fiber, fat, protein, and nonfiber carbohydrate. J. Dairy Sci. 100:3591-3610.

Windschitl, P. M., and M. D. Stern. 1988. Evaluation of calcium lignosulfonate-treated soybean meal as a source of rumen protected protein for dairy cattle. J. Dairy Sci. 71:3310-3322.

Wonsil, B. J., J. H. Herbein, and B. A. Watkins. 1994. Dietary and ruminally derived trans-18:1 fatty acids alter bovine milk lipids. J. Nutr. 124:556-565.

Yang, W. Z., and K. A. Beauchemin. 2004. Grain processing, forageto-concentrate ratio, and forage length effects on ruminal nitrogen degradation and flows of amino acids to the duodenum. J. Dairy Sci. 87:2578-2590

Yang, W. Z., K. A. Beauchemin, K. M. Koenig, and L. M. Rode. 1997. Comparison of hull-less barley, barley, or corn for lactating cows:
Effects on extent of digestion and milk production. J. Dairy Sci. 80(Suppl. 10):2475-2486.

Zerbini, E., C. E. Polan, and J. H. Herbein. 1988. Effect of dietary soybean meal and fish meal on protein digesta flow in Holstein cows during early and midlactation. J. Dairy Sci. 71:1248-1258.

\section{ORCIDS}

A. J. Fleming @ https://orcid.org/0000-0002-6122-5962

H. Lapierre @ https://orcid.org/0000-0002-1162-7226

P. J. Kononoff ๑ https://orcid.org/0000-0001-6069-2174

W. P. Weiss @ https://orcid.org/0000-0003-3506-4672

M. D. Hanigan @ https://orcid.org/0000-0002-5639-9677 